\title{
Cisplatin-induced emesis: systematic review and meta-analysis of the ferret model and the effects of $5-\mathrm{HT}_{3}$ receptor antagonists
}

\author{
N. Percie du Sert $\cdot$ J. A. Rudd $\cdot$ C. C. Apfel · \\ P. L. R. Andrews
}

Received: 22 March 2010 / Accepted: 16 April 2010 / Published online: 28 May 2010

(C) The Author(s) 2010. This article is published with open access at Springerlink.com

\begin{abstract}
Purpose The ferret cisplatin emesis model has been used for $\sim 30$ years and enabled identification of clinically used anti-emetics. We provide an objective assessment of this model including efficacy of $5-\mathrm{HT}_{3}$ receptor antagonists to assess its translational validity.

Methods A systematic review identified available evidence and was used to perform meta-analyses.

Results Of 182 potentially relevant publications, 115 reported cisplatin-induced emesis in ferrets and 68 were included in the analysis. The majority $(n=53)$ used a $10 \mathrm{mg} \mathrm{kg}^{-1}$ dose to induce acute emesis, which peaked after $2 \mathrm{~h}$. More recent studies $(n=11)$ also used $5 \mathrm{mg} \mathrm{kg}^{-1}$, which induced a biphasic response peaking at $12 \mathrm{~h}$ and $48 \mathrm{~h}$. Overall, $5-\mathrm{HT}_{3}$ receptor antagonists reduced cisplatin $\left(5 \mathrm{mg} \mathrm{kg}^{-1}\right)$ emesis by $68 \%(45-91 \%)$ during the acute phase (day 1) and by $67 \%(48-86 \%)$ and $53 \%(38-68 \%$, all $P<0.001$ ), during the delayed phase (days 2,3 ). In an
\end{abstract}

N. Percie du Sert $(\bowtie) \cdot$ P. L. R. Andrews

Division of Basic Medical Sciences,

St George's University of London,

Cranmer Terrace, London SW17 0RE, UK

e-mail:npercied@sgul.ac.uk

J. A. Rudd

Emesis Research Group, School of Biomedical Sciences,

Faculty of Medicine, The Chinese University of Hong Kong,

Shatin, New Territories, Hong Kong, SAR, China

C. C. Apfel

Perioperative Clinical Research Core,

Department of Anesthesia and Perioperative Care,

UCSF Medical Center at Mt Zion, University of California

San Francisco, San Francisco, CA, USA analysis focused on the acute phase, the efficacy of ondansetron was dependent on the dosage and observation period but not on the dose of cisplatin.

Conclusion Our analysis enabled novel findings to be extracted from the literature including factors which may impact on the applicability of preclinical results to humans. It reveals that the efficacy of ondansetron is similar against low and high doses of cisplatin. Additionally, we showed that $5-\mathrm{HT}_{3}$ receptor antagonists have a similar efficacy during acute and delayed emesis, which provides a novel insight into the pharmacology of delayed emesis in the ferret.

Keywords Cisplatin - Emesis · Ferret · Meta-analysis . Systematic review $\cdot$ Ondansetron $\cdot 5-\mathrm{HT}_{3}$ receptor antagonist $\cdot$ Granisetron $\cdot$ Tropisetron
Abbreviations
5- $\mathrm{HT}_{3} \quad$ 5-Hydroxytryptamine 3
$\mathrm{NK}_{1} \quad$ Neurokinin $_{1}$
i.v. Intravenous
i.p. Intraperitoneal
p.o. Per os, oral
s.c. Sub-cutaneous
$\mathrm{R}+\mathrm{V} \quad$ Retches and vomits
SD Standard deviation
CI Confidence interval

\section{Introduction}

It is generally accepted that nausea and vomiting (emesis) are components of a protective mechanism by which the human body defends itself against ingested toxins. However, the emetic reflex can be triggered inappropriately, and 
nausea and vomiting are also relatively common side effects of drugs in current use (e.g. morphine, anti-cancer chemotherapy) as well as dose-limiting toxicities, which may limit the development of novel chemical entities intended for the treatment of a range of diseases (e.g. phosphodiesterase-IV inhibitors for the treatment of asthma [135]). The multi-system nature of the emetic reflex coordinated in the brainstem and the behavioural and sensory expression of nausea have meant that, to date, preclinical studies of the mechanisms involved and identification of novel anti-emetic agents have involved studies in whole animals (conscious, anaesthetised or decerebrate) [61]. Nausea and vomiting are particularly associated with the treatment of cancer by cytotoxic drugs (e.g. cisplatin), symptoms which patients find particularly distressing and impact upon compliance with treatment. In the absence of anti-emetic prophylaxis, cisplatin induces nausea and vomiting in virtually all patients [109]; the emetic response lasts up to 5 days on each cycle and is characterised by an intense acute phase lasting $\sim 24 \mathrm{~h}$ and a less intense but more protracted delayed phase peaking during the period 48-72 $\mathrm{h}$ following the administration of cisplatin [72]. In the early 1980s, the ferret (Mustela putorius furo L.) was reported to develop an acute emetic response to high-dose cisplatin $\left(8-10 \mathrm{~m} \mathrm{~kg}^{-1}\right)$ and was proposed as an alternative model to the dog, cat and monkey (commonly used at the time) to study cytotoxic drug-induced emesis and identify potential anti-emetic agents [40]. Subsequently, the acute cisplatin model was modified and the dose of cisplatin lowered to $5 \mathrm{mg} \mathrm{kg}^{-1}$ to investigate delayed emesis [114]. The ferret model of cisplatin-induced emesis was rapidly adopted for the investigation of new anti-emetic agents and was pivotal in establishing the anti-emetic efficacy of 5-hydroxytryptamine ${ }_{3}\left(5-\mathrm{HT}_{3}\right)$ [94] and tachykinin $\mathrm{NK}_{1}$ receptor antagonists [148], which are both currently in widespread use for the treatment of chemotherapy-induced nausea and vomiting [109].

The use and benefit of animal models in research is regularly questioned and anecdotal evidence or unsupported claims, as opposed to quantitative support, are too often used as justifications [88, 105]. There has recently been a growing interest in systematic reviews and meta-analyses to assess the validity of animal models (i.e. how preclinical research has informed clinical research) and their utility in drug discovery (i.e. evaluate data and inform the decision to carry out a clinical trial). The Nuffield Council for Bioethics [101] recommends that such reviews are undertaken to "evaluate more fully the predictability and transferability of animal models". Such analyses also have implications for the application of the principles of the 3Rs (Replacement, Refinement, Reduction) to animal experimentation [61, 68] and should inform preclinical guidelines produced by regulators (e.g. [37]). Recently, systematic reviews and meta-analysis of animal models of stroke have been carried out. A retrospective study concluded that even though individual studies had reported beneficial effects of the calcium channel blocker nimodipine; overall, the preclinical data available were not conclusive [62], which is consistent with the fact that this type of drug was without effect in humans [63] and highlights the necessity of quantifying animal data adequately before starting clinical trials. Later studies assessed the preclinical evidence of the effect of potential treatments in experimental stroke and characterised their neuroprotective properties in order to identify research priorities [78-80].

The cisplatin-induced emesis ferret models provide a unique opportunity to assess the value of systematic reviews in specific areas, because the wealth of data available in this relatively circumscribed area allows assessment of two characteristics of a model: the response to cisplatin itself, and the anti-emetic potential of agents that are currently used in humans. The aim of this systematic review is twofold: firstly, this study intends to provide an objective measure of the characteristics of cisplatin-induced emesis in the ferret, in terms of the latency, magnitude (number of retches and vomits) and profile of the emetic response. Secondly, the effect of 5- $\mathrm{HT}_{3}$ receptor antagonists in the ferret model will be quantified; the present study will assess the efficacy of ondansetron against the acute phase of emesis; additionally, we will compare the overall effect of $5-\mathrm{HT}_{3}$ receptors antagonists against the acute and delayed phases of emesis.

This paper is the first systematic review and meta-analysis covering a model of emesis and anti-emetics. It provides evidence, which supports the predictability of the model and identifies new features of the model not apparent from individual studies. Additionally, it shows the limitations of the model and identifies opportunities for enhanced animal welfare according to the principles of the " $3 \mathrm{Rs}$ " formulated by Russell and Burch over 50 years ago [126].

\section{Methods}

Search strategy

Studies were identified from Pubmed (1974 to March 2007) and Embase (1980 to March 2007) using the combination of words: CISPLATIN and FERRET; hand searching of abstracts of scientific meetings and personal files. All references of newly identified publications were also screened until no further eligible references were found. Language was not restricted. Values for data expressed graphically were either requested from authors or measured from the graphs. Corresponding authors were also contacted to obtain data that was not reported clearly enough in their publications. 
Inclusion criteria:

- Report of cisplatin-induced emesis in the ferret

- Emetic response documented, and quantified by at least one of the following: latency to onset of emesis (retching or vomiting), number of animals developing emesis, number of retches $(\mathrm{R})$, vomits $(\mathrm{V})$, retches and vomits $(\mathrm{R}+\mathrm{V})$ defined according to our definition and reported as mean only or mean \pm SEM or SD, and number of ferrets per group.

Exclusion criteria:

- Number of animals not stated

- Emetic response investigated under anaesthesia

- Emetic response not reported as the number of animals developing emesis, or mean latency, or mean number of retches and vomits compatible with the standard definition of emesis.

Emesis was defined as retching (i.e. rhythmic abdominal contractions against a closed glottis) and vomiting (i.e. rhythmic abdominal contractions associated with the oral expulsion of solid or liquid materials from the gastrointestinal tract) $[14,22,89]$. Reports stating this definition in their methods section were included in this study; if the definition was absent or unclear, evaluation of the results reported and their inclusion in this quantitative review were left to the judgement of the investigator and discussed with co-workers; reports were included:

- If the same team had published other reports clearly stating this definition or a member of the team-most senior or corresponding author-was contacted to confirm the definition used to characterise emesis

- If the report referred to publications clearly stating this definition

- If the definition stated allowed the identification of the number of retches and/or vomits according to our definition.

The latency (time to onset of emesis) was a potential confounding factor as many publications reported the latency as a mean for all the animals in the groups, including those free of emesis, in which case the latency was taken as the total duration of the observation time. All latencies were recalculated as the mean latency to the first retch or vomit in animals that developed emesis only. The latency was either measured as the time to the first retch, the time to the first vomit or the time to the first emetic episode. All the latencies reported were included combined together, as it was considered that only a minimal period of time separates the first retch from the first vomit [144], a more rigid approach including only the studies with either one or the other measurement and excluding those reporting the latency to the first emesis or emetic episode would have induced a greater error.

Data extraction and analysis

Meta-analysis: the ferret model of cisplatin-induced emesis

The number of retches $(\mathrm{R})$, vomits $(\mathrm{V})$, retches + vomits $(\mathrm{R}+\mathrm{V})$ and/or latency data from control groups (i.e. animals that received no other drug than cisplatin or cisplatin and an inactive-i.e. non-emetogenic_-vehicle) were extracted as mean, standard deviations (SD) and number of animals per group. Weighted mean and weighted mean of the SD were calculated and a one-way ANOVA was carried out to compare the onset of emesis following different doses of cisplatin. Unless stated, all results are reported as mean \pm SD. In order to identify variables modulating the emetic response, subgroup analyses were carried out according to criteria such as the vehicle used, duration of the observation period, the mode of administration of cisplatin (i.v. or i.p.), the use of anaesthesia and the recovery time prior to the emetic challenge, the strain (fitch or albino), sex and origin of the ferrets. This analysis was only carried out on the most common doses of cisplatin used to induce acute $\left(10 \mathrm{mg} \mathrm{kg}^{-1}\right)$ and acute and delayed emesis in the ferret $\left(5 \mathrm{mg} \mathrm{kg}^{-1}\right)$; the two doses were treated separately. Weighted means and the weighted mean of the SDs were calculated and profiles of emesis were constructed with Graphpad Prism ${ }^{\circledR}$ version 5.0, Graphpad Software Inc., San Diego, USA. Differences were assessed by a one-way analysis of variance (ANOVA) or independent sample $t$ tests as appropriate. Descriptive statistics and comparisons were carried out using SPSS ${ }^{\circledR}$ 14.00, SPSS Inc., Chicago, USA and CLINSTAT (M. Bland). Differences were considered statistically significant when $P<0.05$.

\section{Meta-analysis: the effect of anti-emetics}

For the meta-analysis of the effects of anti-emetics, comparisons were only included if the effect of a prophylactic antiemetic treatment was reported, the 3 outcomes measured were: the number of $\mathrm{R}+\mathrm{V}$, proportion of animals experiencing emesis and latency to the onset of emesis. To calculate the effect size and its $95 \%$ confidence interval for the continuous outcomes (i.e. $\mathrm{R}+\mathrm{V}$ and latency), the mean outcome for the treatment group, and the SDs in treatment and control groups were expressed as a proportion of the outcome in the control group [80]. Actual data were used for dichotomous outcomes (i.e. the number of animals with emesis). When a control group was used to assess more than one treatment group, the number of animals in the control group was divided by the number of treatment groups and if needed, adjusted to the next integer. This methodology 
is consistent with what has been done in another metaanalysis of animal data in a model of stroke [80]. The effect of ondansetron was examined for each of the 3 outcomes; subgroup analyses were carried out depending on the dose of cisplatin and duration of the observation period, dose, timing and mode of administration of ondansetron, mode of administration of cisplatin, origin of the ferrets, and quality score of the study. Additional analyses examined the effects of 5- $\mathrm{HT}_{3}$ receptor antagonists on the latency to the onset of cisplatin $\left(10 \mathrm{mg} \mathrm{kg}^{-1}\right)$-induced emesis and on the acute and delayed $\mathrm{R}+\mathrm{V}$ induced by $5 \mathrm{mg} \mathrm{kg}^{-1}$ cisplatin (criteria for variation: individual compound). In the later analysis, comparisons on a given day were only included if the antiemetic treatment started before or at the start of the 24-h period and was continued throughout the day.

Methodological quality of individual studies was assessed according to criteria chosen to evaluate the reliability of the data extracted. These criteria were: no duplicate publication identified-confirmed or suspected-, retch and vomit clearly defined or definition confirmed by authors, latency to the first retch or vomit given, SEM/SD given for the mean latency, number of retches and vomits or $\mathrm{R}+\mathrm{V}$ given, $\mathrm{SEM} / \mathrm{SD}$ given for the mean $\mathrm{R}+\mathrm{V}$, number of ferrets completely protected given (1 point per criterion fulfilled), origin, sex, strain and body weight of the ferrets given (1/2 point per criterion fulfilled). Each study was given a quality score out of a possible total of 9 points. The DerSimonian and Laird method was used to combine dichotomous (risk difference [RD]) and continuous data (weighted mean difference [WMD]). The random-effects model was chosen over the fixed effect assumption because it incorporates inter-study differences into the analysis of the overall treatment efficacy [28]. The data were analysed with Review Manager (RevMan. Version 5.0 for Macintosh. Copenhagen: The Nordic Cochrane Centre, The Cochrane Collaboration, 2008). All effect estimates are reported as mean and $95 \%$ confidence intervals. $Z$ tests were used to assess the overall effect of treatments and Chisquared $\left(\chi^{2}\right)$ tests were used to assess the heterogeneity along with $I^{2}$, which describes the percentage of the variability in effect estimates that is due to heterogeneity rather than chance (a value greater than $50 \%$ may be considered substantial heterogeneity). The differences between the treatment effects of sub-categories of a particular outcome were assessed by a $Z$ test $[1,87]$, potential publication biases were assessed by Funnel plots [143].

\section{Anti-emetic drugs examined}

Ondansetron: 9-methyl-3-[(2-methylimidazol-1-yl)methyl]2,3-dihydro-1H-carbazol-4-one. Granisetron: 1-methyl- $\mathrm{N}$ (9-methyl-9-azabicyclo[3.3.1]nonan-7-yl)indazole-3-carboxamide. Indisetron: $N$-(3,9-dimethyl-3,9-diazabicy-
clo[3.3.1]nonan-7-yl)-1H-indazole-3-carboxamide. Zacopride: 4-amino- $N$-(1-azabicyclo[2.2.2]octan-8-yl)-5chloro-2-methoxybenzamide. FK1052: (7S)-10-methyl-7[(5-methyl-1H-imidazol-4-yl)methyl]-8,9-dihydro-7H-pyrido[1,2-a]indol-6-one hydrochloride. Dolasetron: (3R)-10oxo-8-azatricyclo[5.3.1. $0^{3,8}$ ] undec-5-yl $1 \mathrm{H}$-indole-3-carboxylate. L-683,877: $2^{1}$-(1-Methyl-1H-indol-3-yl)-)spiro(1azabicyclo[2.2.2] octane-3, $5^{1}\left(4^{1} \mathrm{H}\right)$-oxazole. Ramosetron: (1-methylindol-3-yl)-[(5R)-4,5,6,7-tetrahydro-3H-benzimidazol-5-yl]methanone. Azasetron: $N$-(1-azabicyclo[2.2.2] octan-8-yl)-6-chloro-4-methyl-3-oxo-1,4benzoxazine-8-carboxamide. Renzapride: 4-amino- $\mathrm{N}$ [(5S,6S)-1-azabicyclo[3.3.1]nonan-6-yl]-5-chloro-2-methoxybenzamide. Bemesetron: [(1S,5R)-8-methyl-8-azabicyclo[3.2.1]octan-3-yl] 3,5-dichlorobenzoate.

\section{Results}

Publications

As of March 2007, 182 publications were retrieved, 115 publications describing cisplatin-induced emesis in the ferret were identified, 32 publications were excluded and 83 publication contained usable data (Fig. 1; Tables 1,2). A further 15 publications were excluded on the grounds that data was already reported elsewhere. The remaining 68 publications were either fully or partly included as some papers presented original data and duplicate data together, in this case only the original data was extracted and the duplicate data was ignored.

Out of the 68 publications from which at least one outcome was extracted, 44, 10 and 9 publications reported the effect of at least one $5-\mathrm{HT}_{3}, \mathrm{NK}_{1}$ receptor antagonist and

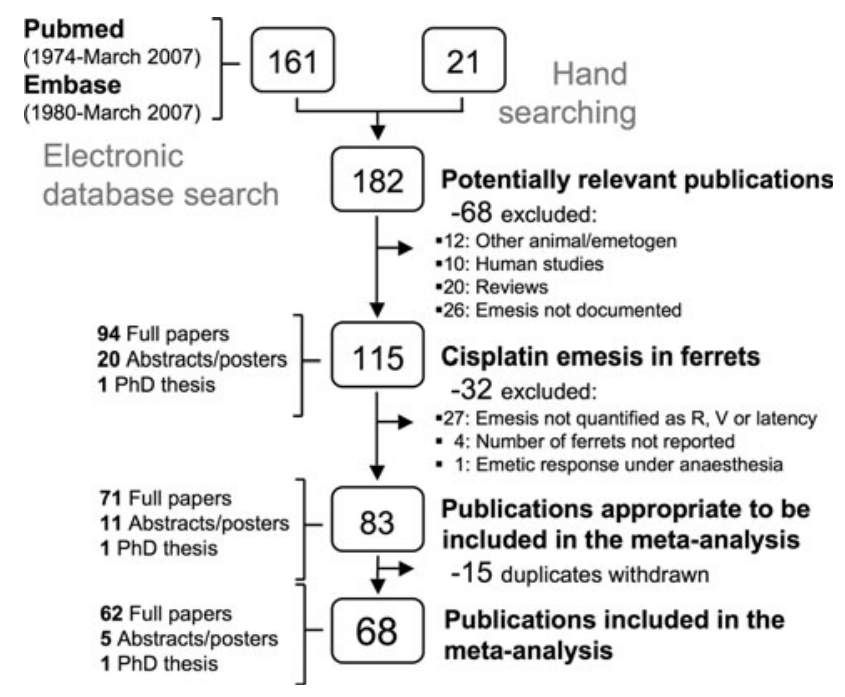

Fig. 1 Flow chart of identified studies. Reproduced and adapted from the QUOROM statement flow diagram [97] 
Table 1 List of 68 included publications

\begin{tabular}{|c|c|c|c|c|c|c|c|}
\hline Study & $\begin{array}{l}\text { Quality } \\
\text { score }\end{array}$ & Cisplatin dose & $\begin{array}{l}\text { Obs. } \\
\text { period }\end{array}$ & Study & $\begin{array}{l}\text { Quality } \\
\text { score }\end{array}$ & Cisplatin dose & $\begin{array}{l}\text { Obs. } \\
\text { period }\end{array}$ \\
\hline Angel et al. (1993) [4] & 7 & $10 \mathrm{mg} \mathrm{kg}^{-1}$, i.v. & $3 \mathrm{~h}$ & Minami et al. (1998) [91] & 6 & $10 \mathrm{mg} \mathrm{kg}^{-1}$, i.p. & $6 \mathrm{~h}$ \\
\hline Barnes et al. (1987) [6] & 6 & $10 \mathrm{mg} \mathrm{kg}^{-1}$, i.v. & $4 \mathrm{~h}$ & Miner et al. (1986a) [94] & 4 & $10 \mathrm{mg} \mathrm{kg}^{-1}$, i.v. & $4 \mathrm{~h}$ \\
\hline Barnes et al. (1988) [5] & 9 & $10 \mathrm{mg} \mathrm{kg}^{-1}$, i.v. & $3 \mathrm{~h}$ & Miner et al. (1987) [96] & 4 & $10 \mathrm{mg} \mathrm{kg}^{-1}$, i.v. & $4 \mathrm{~h}$ \\
\hline Barnes et al. (1991) [7] & 7 & $10 \mathrm{mg} \mathrm{kg}^{-1}$, i.v. & $4 \mathrm{~h}$ & Nakayama et al. (2005) [99] & 8.5 & $5,10 \mathrm{mg} \mathrm{kg}^{-1}$, i.p. & $24,4 \mathrm{~h}$ \\
\hline Bermudez et al. (1988) [9] & 4.5 & $10 \mathrm{mg} \mathrm{kg}^{-1}$, i.v. & $4 \mathrm{~h}$ & Ozaki and Sakamoto (1999) [103] & 7 & $10 \mathrm{mg} \mathrm{kg}^{-1}$, i.v. & $4 \mathrm{~h}$ \\
\hline Bingham et al. (1994) [11] & 4.5 & $12.5 \mathrm{mg} \mathrm{kg}^{-1}$, i.v. & $4 \mathrm{~h}$ & Reynolds et al. (1991) [108] & 6 & $10 \mathrm{mg} \mathrm{kg}^{-1}$, i.p. & $3 \mathrm{~h}$ \\
\hline Blower (1990) [12] & 6 & $10 \mathrm{mg} \mathrm{kg}^{-1}$, i.v. & $4 \mathrm{~h}$ & Rudd et al. (1992) [111] & 5 & $10 \mathrm{mg} \mathrm{kg}^{-1}$, i.v & $4 \mathrm{~h}$ \\
\hline Costall et al. (1986) [21] & 7 & $10 \mathrm{mg} \mathrm{kg}^{-1}$, i.v. & $2 \mathrm{~h}$ & Rudd et al. (1994a) [114] & 6.5 & $10 \mathrm{mg} \mathrm{kg}^{-1}$, i.p. & $40 \mathrm{~h}$ \\
\hline Costall et al. (1987b) [19] & 6 & $10 \mathrm{mg} \mathrm{kg}^{-1}$, i.v. & $2 \mathrm{~h}$ & Rudd and Naylor (1994b) [117] & 5 & $5,10 \mathrm{mg} \mathrm{kg}^{-1}$, i.p. & $24 \mathrm{~h}$ \\
\hline Costall et al. (1987c) [22] & 6.5 & $10,15 \mathrm{mg} \mathrm{kg}^{-1}$, i.v. & $2 \mathrm{~h}$ & Rudd and Naylor (1994c) [118] & 6 & $10 \mathrm{mg} \mathrm{kg}^{-1}$, i.v. & $4 \mathrm{~h}$ \\
\hline Costall et al. (1990a) [20] & 7 & $10,15 \mathrm{mg} \mathrm{kg}^{-1}$, i.v. & $4 \mathrm{~h}$ & Rudd et al. (1996b) [115] & 7.5 & $5,10 \mathrm{mg} \mathrm{kg}^{-1}$, i.p. & $24,40 \mathrm{~h}$ \\
\hline Costall et al. (1990b) [23] & 7 & $10 \mathrm{mg} \mathrm{kg}^{-1}$, i.v. & $4 \mathrm{~h}$ & Rudd and Naylor (1996c) [119] & 7.5 & $5 \mathrm{mg} \mathrm{kg}^{-1}$, i.p. & $24 \mathrm{~h}$ \\
\hline Davis (1988) [26] & 8 & $\begin{array}{l}10,12,20 \\
\mathrm{mg} \mathrm{kg}^{-1} \text {, i.v. }\end{array}$ & $2 \mathrm{~h}$ & Rudd et al. (1996a) [112] & 8 & $10 \mathrm{mg} \mathrm{kg}^{-1}$, i.v. & $4 \mathrm{~h}$ \\
\hline $\begin{array}{l}\text { Delagrange et al. (1996) } \\
{[26,27]}\end{array}$ & 3.5 & $10 \mathrm{mg} \mathrm{kg}^{-1}$, i.p. & $5 \mathrm{~h}$ & Rudd and Naylor (1997) [120] & 8.5 & $10 \mathrm{mg} \mathrm{kg}^{-1}$, i.p. & $24 \mathrm{~h}$ \\
\hline Endo et al. (1990b) [33] & 6 & $7,10 \mathrm{mg} \mathrm{kg}^{-1}$, i.p. & $6 \mathrm{~h}$ & Rudd et al. (1998b) [113] & 5.5 & $10 \mathrm{mg} \mathrm{kg}^{-1}$, i.p. & $24 \mathrm{~h}$ \\
\hline Endo et al. (1994) [36] & 6.5 & $10 \mathrm{mg} \mathrm{kg}^{-1}$, i.p. & $6 \mathrm{~h}$ & Rudd et al. (2006a) [122] & 6 & $10 \mathrm{mg} \mathrm{kg}^{-1}$, i.p. & $6 \mathrm{~h}$ \\
\hline Fink-Jensen (1992) [38] & 5 & $10 \mathrm{mg} \mathrm{kg}^{-1}$, i.v. & $4 \mathrm{~h}$ & Rycroft et al. (1996) [127] & 5 & $10 \mathrm{mg} \mathrm{kg}^{-1}$, i.v. & $4 \mathrm{~h}$ \\
\hline Florczyk et al. (1982) [40] & 5 & $\begin{array}{l}6,8,10 \\
\quad \mathrm{mg} \mathrm{kg}^{-1} \text {, i.v. }\end{array}$ & $4 \mathrm{~h}$ & Sam et al. (2001) [128] & 7.5 & $5 \mathrm{mg} \mathrm{kg}^{-1}$, i.p. & $24 \mathrm{~h}$ \\
\hline Fukunaka et al. (1998) [42] & 8 & $5 \mathrm{mg} \mathrm{kg}^{-1}$, i.p. & $24 \mathrm{~h}$ & Sam et al. (2003) [129] & 7.5 & $5 \mathrm{mg} \mathrm{kg}^{-1}$, i.p. & $24 \mathrm{~h}$ \\
\hline Gonsalves et al. (1996) [47] & 7.5 & $10 \mathrm{mg} \mathrm{kg}^{-1}$, i.p. & $2 \mathrm{~h}$ & Sam et al. (2007) [130] & 7.5 & $5 \mathrm{mg} \mathrm{kg}^{-1}$, i.p. & $24 \mathrm{~h}$ \\
\hline Gylys et al. (1988) [49] & 5 & $12 \mathrm{mg} \mathrm{kg}^{-1}$, i.v. & $4 \mathrm{~h}$ & Schurig et al. (1982) [131] & 5.5 & $8 \mathrm{mg} \mathrm{kg}^{-1}$, i.p. & $4 \mathrm{~h}$ \\
\hline Haga et al. (1993) [50] & 4.5 & $8 \mathrm{mg} \mathrm{kg}^{-1}$, i.v. & $5 \mathrm{~h}$ & Shiroshita et al. (1993) [132] & 6 & $10 \mathrm{mg} \mathrm{kg}^{-1}$, i.p. & $6 \mathrm{~h}$ \\
\hline Hawthorn et al. (1988) [56] & 8.5 & $10 \mathrm{mg} \mathrm{kg}^{-1}$, i.p. & $4 \mathrm{~h}$ & Singh et al. (1997) [134] & 4.5 & $5 \mathrm{mg} \mathrm{kg}^{-1}$, i.p. & $24 \mathrm{~h}$ \\
\hline Higgins et al. (1989) [59] & 5.5 & $9 \mathrm{mg} \mathrm{kg}^{-1}$, i.p. & $3 \mathrm{~h}$ & Taniguchi et al. (2004) [137] & 5 & $5 \mathrm{mg} \mathrm{kg}^{-1}$, i.p. & $24 \mathrm{~h}$ \\
\hline Kamato et al. (1991) [67] & 6.5 & $\begin{array}{c}10 \mathrm{mg} \mathrm{kg}^{-1} \\
\text { i.v., i.p. }\end{array}$ & $4 \mathrm{~h}$ & Tattersall et al. (1992) [139] & 7.5 & $10 \mathrm{mg} \mathrm{kg}^{-1}$, i.v. & $4 \mathrm{~h}$ \\
\hline Kamato et al. (1993) [66] & 6.5 & $10 \mathrm{mg} \mathrm{kg}^{-1}$, i.v. & $6 \mathrm{~h}$ & Tattersall et al. (1993) [142] & 5.5 & $10 \mathrm{mg} \mathrm{kg}^{-1}$, i.v. & $4 \mathrm{~h}$ \\
\hline King and Sanger (2005) [70] & 7.5 & $10 \mathrm{mg} \mathrm{kg}^{-1}$, i.p. & $6 \mathrm{~h}$ & Tattersall et al. (2000) [140] & 3.5 & $\begin{array}{l}\text { 5, } 10 \mathrm{mg} \mathrm{kg}^{-1} \\
\text { i.p., i.v. }\end{array}$ & $24,4 \mathrm{~h}$ \\
\hline Lau et al. (2005) [75] & 7.5 & $10 \mathrm{mg} \mathrm{kg}^{-1}$, i.p. & $2 \mathrm{~h}$ & Tsuchiya et al. (2002) [144] & 7.5 & $5 \mathrm{mg} \mathrm{kg}^{-1}$, i.p. & $24 \mathrm{~h}$ \\
\hline $\begin{array}{l}\text { Lehmann and Karrberg } \\
\text { (1996) [76] }\end{array}$ & 7.5 & $10 \mathrm{mg} \mathrm{kg}^{-1}$, i.v. & $3 \mathrm{~h}$ & Watson et al. (1995) [148]\{ & 7.5 & $10 \mathrm{mg} \mathrm{kg}^{-1}$, i.p. & $2 \mathrm{~h}$ \\
\hline Marr et al. (1992) [81] & 6.5 & $10 \mathrm{mg} \mathrm{kg}^{-1}$, i.v. & $4 \mathrm{~h}$ & Yamakuni et al. (2002) [150] & 5 & $5,10 \mathrm{mg} \mathrm{kg}^{-1}$, i.p. & $24,4 \mathrm{~h}$ \\
\hline Marr et al. (1994a) [82] & 7 & $10 \mathrm{mg} \mathrm{kg}^{-1}$, i.v. & $4 \mathrm{~h}$ & Yamakuni et al. (2006) [149] & 7.5 & $\begin{array}{l}\text { 5, } 10 \mathrm{mg} \mathrm{kg}^{-1} \\
\text { i.p., i.v. }\end{array}$ & $24,4 \mathrm{~h}$ \\
\hline Marr et al. (1994b) [83] & 3.5 & $12.5 \mathrm{mg} \mathrm{kg}^{-1}$, i.v. & $4 \mathrm{~h}$ & Yoshida et al. (1992a) [151] & 4 & $10 \mathrm{mg} \mathrm{kg}^{-1}$, i.v. & $3 \mathrm{~h}$ \\
\hline Miller et al. (1993) [90] & 7 & $10 \mathrm{mg} \mathrm{kg}^{-1}$, i.v. & $4 \mathrm{~h}$ & Yoshida et al. (1993) [153] & 4.5 & $10 \mathrm{mg} \mathrm{kg}^{-1}$, i.v. & $3 \mathrm{~h}$ \\
\hline Minami et al. (1997) [93] & 6 & $10 \mathrm{mg} \mathrm{kg}^{-1}$, i.p. & $6 \mathrm{~h}$ & Yoshikawa et al. (2001b) [157] & 3.5 & $10 \mathrm{mg} \mathrm{kg}^{-1}$, i.v. & $4 \mathrm{~h}$ \\
\hline
\end{tabular}

For each included study, the quality score (out of 9), the dose and mode of administration of cisplatin and the duration of the acute phase observation period are indicated

glucocorticoid, respectively. In terms of outcome, 63 studies reported the latency, which was either measured as the latency to the first retch (13\% of the publications reporting the latency), the latency to the first vomit (16\%) or the latency to the first emetic episode (75\%). Fifty-one studies reported the number of retches and vomits $(\mathrm{R}+\mathrm{V})$ in a given observation time, 37 and 36 studies respectively reported the number of retches and vomits separately. The number of animals with emesis during the duration of the observation time was reported in 45 publications. 
Table 2 List of 47 excluded publications

\begin{tabular}{|c|c|c|c|c|c|}
\hline Study & $\begin{array}{l}\text { Reason for } \\
\text { exclusion }\end{array}$ & Study & $\begin{array}{l}\text { Reason for } \\
\text { exclusion }\end{array}$ & Study & $\begin{array}{l}\text { Reason for } \\
\text { exclusion }\end{array}$ \\
\hline Blum et al. (1992) [13] & Emesis & Gooch et al. (1998) [48] & Anaesthesia & Rudd et al. (2001) [116] & Group number \\
\hline Bountra et al. (1993) [15] & Emesis & Haga et al. (2000) [51] & Emesis & Rudd et al. (2006b) [123] & Duplicate \\
\hline Chevalier et al. (1998) [16] & Emesis & Hale et al. (1998) [53] & Duplicate & Rupniak et al. (1997) [125] & Emesis \\
\hline Clark et al. (1993) [17] & Duplicate & Hale et al. (2000) [52] & Duplicate & Shiroshita et al. (1992) [133] & Emesis \\
\hline Costall et al. (1987a) [18] & Duplicate & Hargreaves et al. (1994) [54] & Duplicate & Stables et al. (1987) [136] & Duplicate \\
\hline Eglen et al. (1993) [31] & Emesis & Hollingworth et al. (2006) [60] & Group number & Tattersall et al. (1990) [138] & Duplicate \\
\hline Eglen et al. (1994) [29] & Emesis & Ito et al. (1990) [64] & Emesis & Tattersall et al. (1996) [141] & Group number \\
\hline Eglen et al. (1995) [30] & Emesis & Kim et al. (2005) [69] & Emesis & Twissell et al. (1993) [145] & Duplicate \\
\hline Endo et al. (1990a) [32] & Duplicate & Lasheras et al. (1996) [74] & Emesis & Van Sickle et al. (2003) [146] & Emesis \\
\hline Endo et al. (1992) [34] & Group number & Matsui et al. (1992) [86] & Emesis & Yoshida et al. (1991) [154] & Emesis \\
\hline Endo et al. (1995) [35] & Emesis & Minami et al. (1991) [92] & Duplicate & Yoshida et al. (1992b) [152] & Emesis \\
\hline Fitzpatrick et al. (1990) [39] & Emesis & Miner et al. (1986b) [95] & Duplicate & Yoshikawa et al. (1996) [155] & Emesis \\
\hline Florczyk et al. (1981) [41] & Duplicate & Monkovic et al. (1988) [98] & Emesis & Yoshikawa et al. (2001a) [156] & Emesis \\
\hline Gardner et al. (1994) [45] & Emesis & Ohta et al. (1996) [102] & Emesis & Youssefyeh et al. (1992a) [159] & Duplicate \\
\hline Gardner et al. (1995) [46] & Emesis & Price et al. (1990) [107] & Emesis & Youssefyeh et al. (1992b) [158] & Duplicate \\
\hline Gardner et al. (1996) [44] & Emesis & Rudd et al. (1998a) [121] & Emesis & & \\
\hline
\end{tabular}

Reason for exclusion is indicated as: duplicate: data published elsewhere; group number: number of animals in the group missing; emesis: emesis not quantified as number of animals free of emesis, number of retches, number of vomits or latency, or emesis not defined; anaesthesia: emetic response investigated in anaesthetized animals

Meta-analysis: the ferret model of cisplatin induced emesis

\section{Dose of cisplatin}

The latency to the onset of emesis was dose dependant; the time of onset was significantly delayed following a dose of cisplatin of $5 \mathrm{mg} \mathrm{kg}^{-1}$, compared with higher doses (6$20 \mathrm{mg} \mathrm{kg}^{-1}$, one-way ANOVA followed by Bonferroni post-tests, see Fig. 2). Additionally, differences between the doses of $6-20 \mathrm{mg} \mathrm{kg}^{-1}$ were detected $(P<0.001$, one way ANOVA) and the latency shortened when the dose increased.

\section{The $10 \mathrm{mg} \mathrm{kg}^{-1}$ cisplatin model}

The duration of the observation period varied from 2 to $40 \mathrm{~h}$ (at which time the animals were killed). The most common observation period was $4 \mathrm{~h}$, during which $107 \pm 48 \mathrm{R}+\mathrm{V}$ ( $n=199,22$ studies) were observed. In studies using 2, 3, 6, 24 and $40 \mathrm{~h}$ observation periods, $79 \pm 35 \mathrm{R}+\mathrm{V}$ ( $n=40,6$ studies $), 101 \pm 48 \mathrm{R}+\mathrm{V}(n=29,3$ studies), $170 \pm 56 \mathrm{R}+\mathrm{V}(n=73,8$ studies $), 204 \pm 52 \mathrm{R}+\mathrm{V}$ ( $n=16,3$ studies) and $188 \mathrm{R}+\mathrm{V}(n=4,1$ study) were observed, respectively. The number of $\mathrm{R}+\mathrm{V}$ significantly increased as the observation period increased up to $24 \mathrm{~h}$ (one-way ANOVA, $P<0.001$ ). The intensity of emesis reached a maximum after $2 \mathrm{~h}$ and decreased to a very low level (less that $5 \mathrm{R}+\mathrm{V}$ per hour) from $3 \mathrm{~h}$ onward post cisplatin (Fig. 3a).

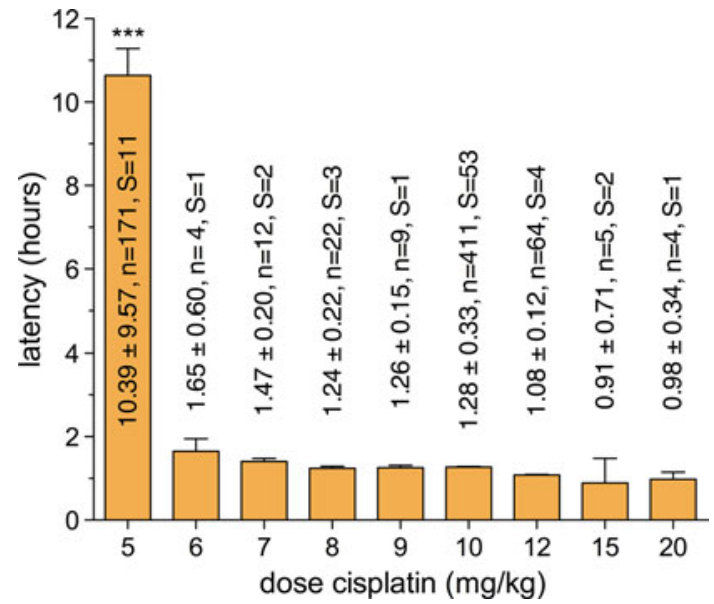

Fig. 2 Latency to the onset of emesis (first retch, vomit or vomiting episode) induced by various doses of cisplatin. Data collected from 64 studies involving 702 animals and plotted on the graph as weighted mean \pm SD. Differences between the doses were assessed by one-way ANOVA followed by Bonferroni post-tests, $* * * p<0.0001$ compared with all other doses in the post-tests. The exact latency values, the number of ferrets from which those values were calculated $(n)$ and the number of studies from which this data was extracted $(S)$ are given above each column

The latency to the onset of emesis was shorter when cisplatin was administered intravenously $(1.16 \pm 0.35 \mathrm{~h}$, $n=277)$ compared to intraperitoneally $(1.51 \pm 0.29 \mathrm{~h}$, $n=134, P<0.001$, independent sample $t$ test). However, the route of administration was directly related to the use of anaesthesia, and all the animals injected with cisplatin 

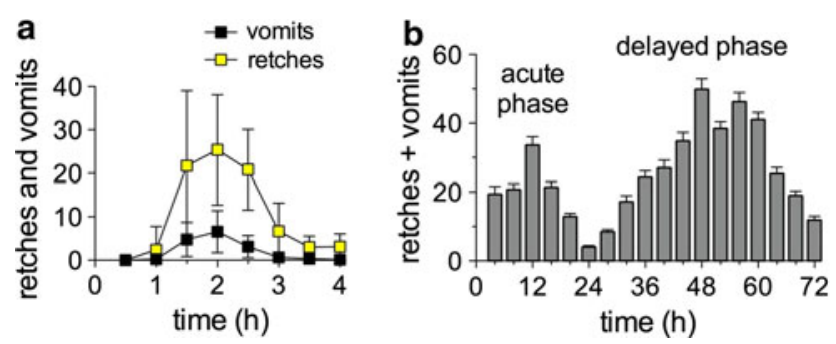

Fig. 3 Profile of emesis induced by $10 \mathrm{mg} \mathrm{kg}^{-1}$ (a) and $5 \mathrm{mg} \mathrm{kg}^{-1}$ (b) cisplatin in the ferret. a Data plotted as mean vomits \pm SD per $30 \mathrm{~min}$ periods, collected from 6 studies involving 34 animals and mean retches \pm SD, collected from 4 of those studies involving 20 out of the 34 animals. b Data plotted as weighted mean $\mathrm{R}+\mathrm{V} \pm \mathrm{SD}$ per 4 -h periods collected from 9 studies involving 92 animals

intravenously (i.v.) had prior anaesthesia during which an i.v. line was implanted or were anaesthetised at the time of cisplatin injection, and prior anaesthesia was not reported in any of the animals that received an intraperitoneal (i.p.) injection of cisplatin. The recovery period between anaesthesia and the administration of cisplatin did not make a difference as ferrets that received cisplatin under anaesthesia developed emesis with a latency of $1.21 \pm 0.32 \mathrm{~h}$ $(n=93)$, and those allowed up to 3 and more than 3 days recovery developed emesis with a latency of $1.11 \pm 0.31 \mathrm{~h}$ $(n=51)$ and $1.13 \pm 0.46 \mathrm{~h}(n=89)$, respectively (one-way ANOVA, $P=0.21)$. The use of an injectable anaesthetic (sodium pentobarbital $30-35 \mathrm{mg} \mathrm{kg}^{-1}$ i.p.) further shortened the latency $(0.95 \pm 0.14 \mathrm{~h}, n=46)$ compared to volatile anaesthetics $(1.21 \pm 0.39 \mathrm{~h}, \quad n=176, \quad P<0.001$, independent sample $t$ test).

Intraperitoneal cisplatin induced a more severe emetic response and $156 \pm 41 \mathrm{R}+\mathrm{V}(n=19)$ and $172(n=65, \mathrm{SD}$ not available) were quantified over 4 and $6 \mathrm{~h}$, respectively, compared to $102 \pm 52 \mathrm{R}+\mathrm{V}(n=180, P<0.001$, independent sample $t$ test) and 152 ( $n=8$, SD not available) following i.v. cisplatin injection (with prior anaesthesia). No differences were observed over an observation period of $2 \mathrm{~h}$ (i.p.: $72 \pm 41, n=22$; i.v.: $88 \pm 32, n=18, P=0.194$, independent samples $t$ test). There was not enough data available on the emetic response quantified for 3, 24 and $40 \mathrm{~h}$ to investigate the influence of the mode of administration of cisplatin and the use of anaesthesia.

In animals that did not receive any vehicle, the latency was $1.39 \pm 0.20 \mathrm{~h}(n=18)$ and ferrets had $92 \pm 15 \mathrm{R}+\mathrm{V}$ $(n=5)$. Different vehicles such as saline/distilled water $(1.30 \pm 0.38 \mathrm{~h}, n=296 ; 97 \pm 31 \mathrm{R}+\mathrm{V}, n=125)$, propylene glycol $(1.23 \pm 0.06 \mathrm{~h}, n=4)$, PEG $300(1.79 \pm 0.18 \mathrm{~h}$, $n=5)$, Tween $80(1.22 \pm 0.19 \mathrm{~h}, n=8)$ and methyl cellulose $(1.13 \pm 0.25 \mathrm{~h}, n=5)$ impacted on the latency $P<0.0001$, one-way ANOVA) but no significant differences were found compared to the group that received no vehicle $(P>0.05$, Bonferroni post-tests $)$. Glucose
$(1.33 \pm 0.24 \mathrm{~h}, n=7 ; 148 \pm 100 \mathrm{R}+\mathrm{V}, n=7)$ was also found to increase the number of $\mathrm{R}+\mathrm{V}(P<0.05$, one-way ANOVA and Bonferroni post-tests).

No differences were detected in latency or number of $\mathrm{R}+\mathrm{V}$ over $4 \mathrm{~h}$ in groups of male ferrets only compared to groups of males and females $(P>0.05$, independent sample $t$ tests). The latency was significantly reduced in albino ferrets $(1.07 \pm 0.14 \mathrm{~h}, n=29)$ compared to fitch ferrets (1.34 $\pm 0.20 \mathrm{~h}, n=70)$ and mixed groups of albino and fitch ferrets $(1.25 \pm 0.36 \mathrm{~h}, n=108, P<0.05$, one-way ANOVA and Bonferroni post-tests) but not enough data were available to compare the number of $\mathrm{R}+\mathrm{V}$.

The latency to the onset of emesis was significantly longer in ferrets bred in New Zealand $(1.73 \pm 0.37 \mathrm{~h}$, $n=11)$ compared to animals bred in the UK $(1.25 \pm$ $0.44 \mathrm{~h}, n=170)$ and in the USA $(1.31 \pm 0.19 \mathrm{~h}, n=176$, $P<0.05$, one-way ANOVA and Bonferroni post-tests). No differences were detected in the number of $\mathrm{R}+\mathrm{V}$ over $4 \mathrm{~h}$ $(P>0.05)$, but the number of $\mathrm{R}+\mathrm{V}$ over $2 \mathrm{~h}$ was reduced in New Zealand ferrets $(40 \pm 41 \mathrm{R}+\mathrm{V}, n=6)$ compared to U.K. animals ( $88 \pm 32 \mathrm{R}+\mathrm{V}, n=18, P=0.007$, independent sample $t$ tests). As all the ferrets originating from $\mathrm{New}$ Zealand were challenged with an intraperitoneal dose of cisplatin, a sub-analysis was carried out only in animals administered cisplatin i.p. and the delay in latency was still significant in ferrets bred New Zealand compared to animals bred in the UK $(1.43 \pm 0.46 \mathrm{~h}, n=29, P<0.05)$ but not to animals bred in the USA $(1.51 \pm 0.21 \mathrm{~h}, n=84$, $P>0.05$, one-way ANOVA and Bonferroni post-tests).

\section{The $5 \mathrm{mg} \mathrm{kg}^{-1}$ cisplatin model}

(acute and delayed emesis model)

Fourteen studies investigated cisplatin-induced acute and delayed emesis in the ferret; cisplatin was administered i.p. in all studies and no study reported prior use of anaesthesia. A biphasic profile of emesis was observed; the acute phase started $10.51 \pm 0.58 \mathrm{~h}(n=156)$ after cisplatin administration, peaked after $12 \mathrm{~h}$ and a nadir was reached after $24 \mathrm{~h}$ (Fig. 3b). The delayed phase was more intense than the acute phase and reached a peak $48 \mathrm{~h}$ post cisplatin before gradually decreasing in intensity during the next $24 \mathrm{~h}$, until $72 \mathrm{~h}$ post cisplatin, at which time a small amount of emesis still persisted. $105 \pm 83 \mathrm{R}+\mathrm{V}(n=215)$ and $340 \pm 171$ ( $n=153$ ) were observed during the acute and delayed phase, respectively $(161 \pm 98 \mathrm{R}+\mathrm{V}$ during day 2 and $179 \pm 94 \mathrm{R}+\mathrm{V}$ during day $3, n=130)$. Overall, $448 \pm 231$ $\mathrm{R}+\mathrm{V}(n=153)$ were observed during the entire 72 -h period.

In animals that did not receive any vehicle, the latency was $11.76 \pm 9.86 \mathrm{~h}(n=98)$ and animals that received i.p. injections of vehicles such as saline, distilled water and $10 \% \mathrm{NaHCO}_{3}$ had a latency of $5.52 \pm 3.32 \mathrm{~h}(n=12)$, $8.74 \pm 8.61 \mathrm{~h}(n=41)$ and $5.71 \pm 5.66 \mathrm{~h}(n=5)$, respectively. 
Overall, the injection of a vehicle had an impact on the latency $(P<0.0001$, one-way ANOVA) but no specific differences were detected compared to the group that did not receive any vehicle $(P>0.05$, Bonferroni post-tests). None of the vehicles had a significant impact on the number of $\mathrm{R}+\mathrm{V}$ during the acute or the delayed phase $(P>0.05$, one-way ANOVA). Neither the strain nor the sex of the ferrets had an impact on the latency or the number of $\mathrm{R}+\mathrm{V}$ $(P>0.05$, one-way ANOVA).

Meta-analysis: the effect of anti-emetics

\section{Effect of ondansetron on the acute phase of emesis}

Outcome: number of retches and vomits $(R+V)$ Data for the number of $\mathrm{R}+\mathrm{V}$ was extracted from 11 full papers, 23 comparisons involving 107 ferrets assessed the efficacy of ondansetron versus control during the acute phase of emesis induced by 5 and $10 \mathrm{mg} \mathrm{kg}^{-1}$ cisplatin. As shown in Fig. 4, the overall effect of ondansetron was a reduction of the $\mathrm{R}+\mathrm{V}$ by about $70 \%(-0.69,-0.82$ to -0.55$)$ and this was highly significant $(Z=10.05, P<0.0001)$. A small statistical heterogeneity was detected $\left(\chi^{2}=37.15, d f=23\right.$, $\left.P=0.03 ; I^{2}=38.1 \%\right)$.

Five variants of the acute model of cisplatin-induced emesis were combined in this meta-analysis: emesis induced by $5 \mathrm{mg} \mathrm{kg}^{-1}$ cisplatin and $\mathrm{R}+\mathrm{V}$ quantified for $24 \mathrm{~h}$ and emesis induced by $10 \mathrm{mg} \mathrm{kg}^{-1}$ and $\mathrm{R}+\mathrm{V}$ quantified for 24, 6, 4 and $2 \mathrm{~h}$. Ondansetron significantly reduced the $\mathrm{R}+\mathrm{V}$ in all variants of the model but one; as shown Table 3, the reduction of $\mathrm{R}+\mathrm{V}$ did not reach statistical significance when emesis was induced by $10 \mathrm{mg} \mathrm{kg}^{-1}$ cisplatin and quantified for $24 \mathrm{~h}$. There was a trend for the effect of ondansetron to increase with shorter observation times $(41,68,70$ and $93 \%$ reduction for $24,6,4$ and 2-h observation periods, respectively) but this did not reach statistical significance. The $\mathrm{R}+\mathrm{V}$ reduction was dose-dependent, doses of $1-10 \mathrm{mg} \mathrm{kg}^{-1}$ afforded a more effective protection than lower doses of $0.1-0.5 \mathrm{mg} \mathrm{kg}^{-1}$ (40 and $83 \%$, respectively, $Z=2.52, P=0.010$ ). The regimen of ondansetron administration did not change the outcome; the effect of ondansetron was similar with i.v., i.p., and s.c. injections $(Z$ tests, $P>0.05)$ and ferrets treated $30 \mathrm{~min}$ prior to cisplatin administration received the same degree of protection as ferrets treated at the time of cisplatin injection $(Z=0.04, P=0.965$, see Table 3$)$. With longer observation periods, ondansetron three times daily was as effective as twice-daily injections $(Z=0.05, P=0.959)$. Ondansetron had the same efficacy on the $\mathrm{R}+\mathrm{V}$ induced by an i.p. or an i.v. dose of cisplatin $(Z=1.07, P=0.287)$ and the origin of the animals or the quality score of the studies (see Table 1) did not influence the outcome ( $Z$ tests, $P>0.05)$.

Outcome: number of animals with emesis Data on the number of animals with emesis was extracted from 14 publications; 28 comparisons involving 256 ferrets were identified. The global estimate of the effect of ondansetron was
Fig. 4 Efficacy of ondansetron number of retches + vomits during the acute phase of emesis induced by cisplatin 5 or $10 \mathrm{mg} \mathrm{kg}^{-1}$. Point estimates and 95\% confidence intervals for each of the ondansetron versus control comparisons ranked by dose. The effect estimate was computed as the weighted mean difference $(W M D)$ and expressed as the proportion of retches and vomits in the control group. An effect estimate of -1 indicates that emesis was abolished in the treatment group, 0 indicates that the treatment had no effect on the $\mathrm{R}+\mathrm{V}$ response and an effect estimate $>0$ indicates that the treatment increased the number of $\mathrm{R}+\mathrm{V}$. The size of each square represents the weight of the comparison in the WMD calculation

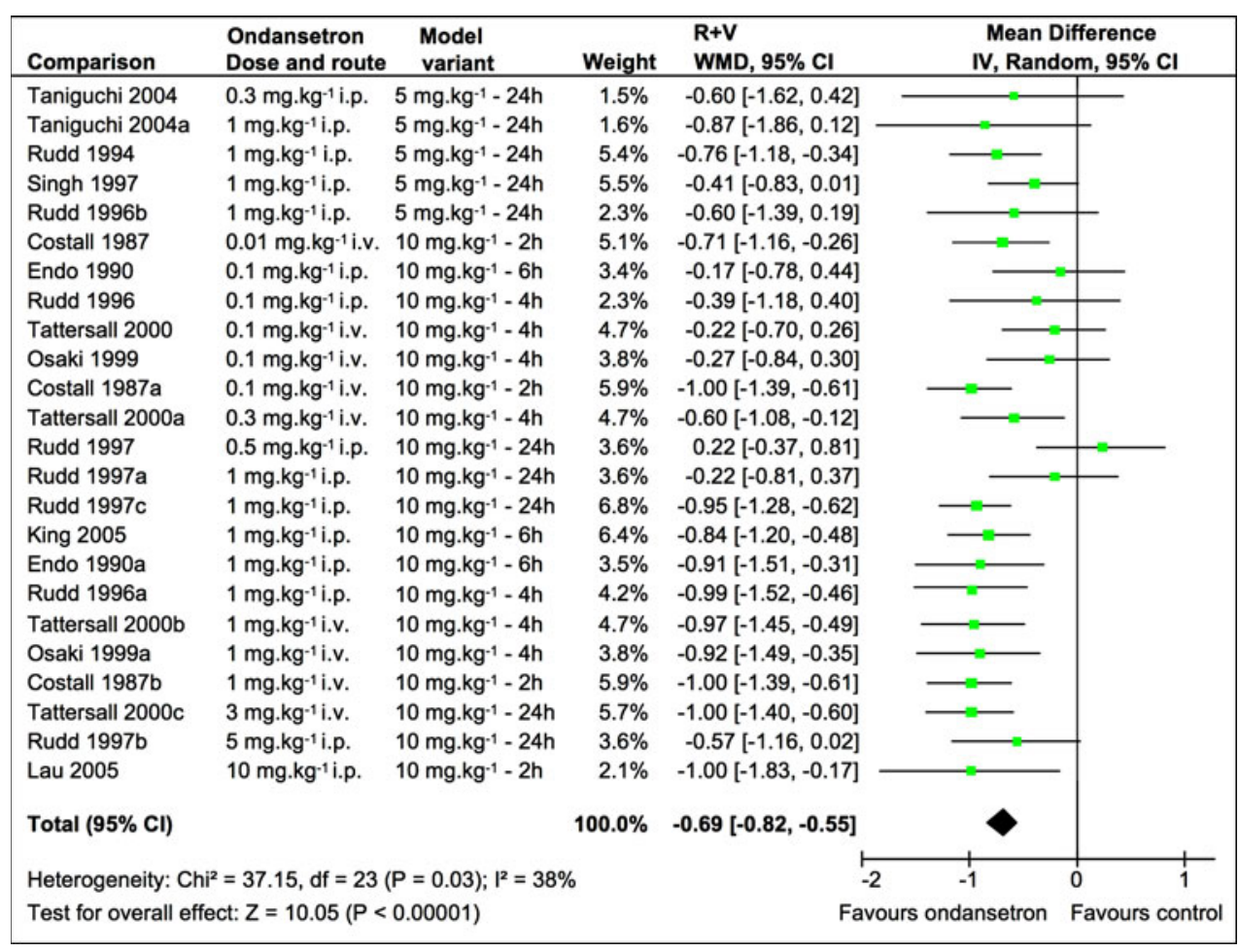


Table 3 Sensitivity analyses of the effect of ondansetron on the number of retches + vomits $(\mathrm{R}+\mathrm{V})$ induced by cisplatin $\left(5 \mathrm{or}^{10} \mathrm{mg} \mathrm{kg}^{-1}\right)$

\begin{tabular}{|c|c|c|c|c|c|}
\hline & $\begin{array}{l}\text { Effect estimate } \\
\text { (proportion of } \\
\mathrm{R}+\mathrm{V} \text { difference) }\end{array}$ & $95 \% \mathrm{CI}$ & $\begin{array}{l}\text { Number of } \\
\text { comparisons }\end{array}$ & $\begin{array}{l}\text { Overall effect } \\
(Z \text { tests })\end{array}$ & $\begin{array}{l}\text { Heterogeneity } \\
\left(\chi^{2}\right)\end{array}$ \\
\hline \multicolumn{6}{|c|}{ Cisplatin dose and duration of the observation period } \\
\hline $5 \mathrm{mg} / \mathrm{kg}(24 \mathrm{~h})$ & -0.61 & -0.87 to -0.35 & 5 & $P<0.001 * * *$ & $P=0.800$ \\
\hline $10 \mathrm{mg} / \mathrm{kg}(24 \mathrm{~h})$ & -0.41 & -0.95 to 0.13 & 4 & $P=0.13$ & $P=0.004^{* *}$ \\
\hline $10 \mathrm{mg} / \mathrm{kg}(6 \mathrm{~h})$ & -0.68 & -1.09 to -0.26 & 3 & $P=0.001 * *$ & $P=0.140$ \\
\hline $10 \mathrm{mg} / \mathrm{kg}(4 \mathrm{~h})$ & -0.70 & -0.94 to -0.46 & 8 & $P<0.001 * * *$ & $P=0.100$ \\
\hline $10 \mathrm{mg} / \mathrm{kg}(2 \mathrm{~h})$ & -0.93 & -1.15 to -0.70 & 4 & $P<0.001 * * *$ & $P=0.750$ \\
\hline \multicolumn{6}{|l|}{ Ondansetron dose } \\
\hline $0.01 \mathrm{mg} \mathrm{kg}^{-1}$ & -0.71 & -1.16 to -0.26 & 1 & $P=0.002 * *$ & N/A \\
\hline $0.1-0.5 \mathrm{mg} \mathrm{kg}^{-1}$ & -0.40 & -0.69 to -0.10 & 8 & $P=0.009 * *$ & $P=0.030^{*}$ \\
\hline $1-10 \mathrm{mg} \mathrm{kg}^{-1}$ & -0.83 & -0.95 to -0.70 & 15 & $P<0.001 * * *$ & $P=0.600$ \\
\hline \multicolumn{6}{|c|}{ Mode of delivery of ondansetron } \\
\hline i.v. & -0.77 & -0.95 to -0.60 & 11 & $P<0.001 * * *$ & $P=0.130$ \\
\hline i.p. & -0.59 & -0.81 to -0.37 & 11 & $P<0.001 * * *$ & $P=0.030^{*}$ \\
\hline s.c. & -0.74 & -1.45 to -0.03 & 2 & $P=0.040^{*}$ & $P=0.710$ \\
\hline \multicolumn{6}{|l|}{ Treatment time } \\
\hline With cisplatin & -0.67 & -0.86 to -0.48 & 15 & $P<0.001 * * *$ & $P=0.010^{*}$ \\
\hline $30 \mathrm{~min}$ before & -0.68 & -1.09 to -0.26 & 3 & $P=0.001 * *$ & $P=0.140$ \\
\hline Twice daily & -0.74 & -1.45 to -0.03 & 4 & $P=0.04 *$ & $P=0.710$ \\
\hline Three times daily & -0.72 & -0.98 to -0.48 & 2 & $P<0.001 * * *$ & $P=0.26$ \\
\hline \multicolumn{6}{|c|}{ Mode of administration of cisplatin } \\
\hline i.v. & -0.77 & -0.97 to -0.57 & 9 & $P<0.001 * * *$ & $P=0.100$ \\
\hline i.p. & -0.62 & -0.81 to -0.44 & 15 & $P<0.001 * * *$ & $P=0.080$ \\
\hline \multicolumn{6}{|l|}{ Animal origin } \\
\hline UK & -0.70 & -0.88 to -0.53 & 15 & $P<0.001 * * *$ & $P=0.020^{*}$ \\
\hline USA & -0.67 & -0.91 to -0.44 & 7 & $P<0.001 * * *$ & $P=0.330$ \\
\hline $\mathrm{NZ}$ & -1.00 & -0.83 to -0.17 & 1 & $P=0.020^{*}$ & N/A \\
\hline \multicolumn{6}{|l|}{ Quality score } \\
\hline Less that $5 / 9$ & -0.65 & -0.95 to -0.34 & 5 & $P<0.001 * * *$ & $P=0.060$ \\
\hline 5 to $7 / 9$ & -0.76 & -0.97 to -0.56 & 9 & $P<0.001 * * *$ & $P=0.260$ \\
\hline 7.5 to $9 / 9$ & -0.65 & -0.88 to -0.42 & 10 & $P<0.001 * * *$ & $P=0.050$ \\
\hline
\end{tabular}

The effect estimate was computed as the weighted mean difference (WMD) and expressed as the proportion of retches and vomits in the control group. An effect estimate of -1 indicates that emesis was abolished in the treatment group, 0 indicates that the treatment had no effect on the $\mathrm{R}+\mathrm{V}$ response and an effect estimate $>0$ indicates that the treatment increased the number of $\mathrm{R}+\mathrm{V}$. The variables examined were the variant of the cisplatin model ( 5 or $10 \mathrm{mg} \mathrm{kg}^{-1}$ cisplatin and the duration of the observation period), the mode of administration of cisplatin, the dose of ondansetron, the regimen of ondansetron administration (mode of delivery and timing relative to cisplatin administration), the animal origin (country animals were bred) and the quality score assigned to the study where comparisons were extracted

-0.33 ( -0.48 to 0.17$)$ indicating that following the administration of cisplatin 5 or $10 \mathrm{mg} \mathrm{kg}^{-1}$, ondansetron abolished the emetic response during the observation time in one-third of the ferrets (see Fig. 5). Overall, this effect was significant $(Z=4.09, P<0.001)$ but a substantial statistical heterogeneity $\left(\chi^{2}=115.13, d f=27, P<0.001, I^{2}=76.5 \%\right)$ was detected between comparisons. Subgroup analyses revealed differences in estimates of efficacy between variants of the model. Whereas ondansetron had a significant effect against emesis induced by $10 \mathrm{mg} \mathrm{kg}^{-1}$ cisplatin and quantified over short observation times (2-4 h) it did not show any significant effect against $10 \mathrm{mg} \mathrm{kg}^{-1}$ cisplatininduced emesis quantified for 6 and $24 \mathrm{~h}$ and $5 \mathrm{mg} \mathrm{kg}^{-1}$ cisplatin-induced emesis quantified for $24 \mathrm{~h}$ (see Table 4). Efficacy increased as the dose increased, and only doses of ondansetron higher than $0.1 \mathrm{mg} \mathrm{kg}^{-1}$ had a significant effect but there was significant heterogeneity within those two subgroups (see Table 4). No statistical differences were detected between i.p., i.v. and oral (p.o.) administration of ondansetron ( $Z$ tests, $P>0.05$ ) but $\chi^{2}$ and $I^{2}$ tests revealed a high degree of heterogeneity in all 3 subgroups. Administered s.c., ondansetron was ineffective but this could 
Fig. 5 Efficacy of ondansetron on the number of animals developing an acute phase of emesis following cisplatin 5 or

$10 \mathrm{mg} \mathrm{kg}^{-1}$. Point estimates and $95 \%$ confidence intervals for each of the ondansetron versus control comparisons ranked by dose. The effect estimate was computed as the risk difference $(R D)$ and represents the proportion of animals with emesis during the duration of the observation period. An effect estimate of 0 indicates that the treatment had no effect on the number of animals with emesis, -1 indicates maximal effect.

The size of each square represents the weight of the comparison in the total RD calculation

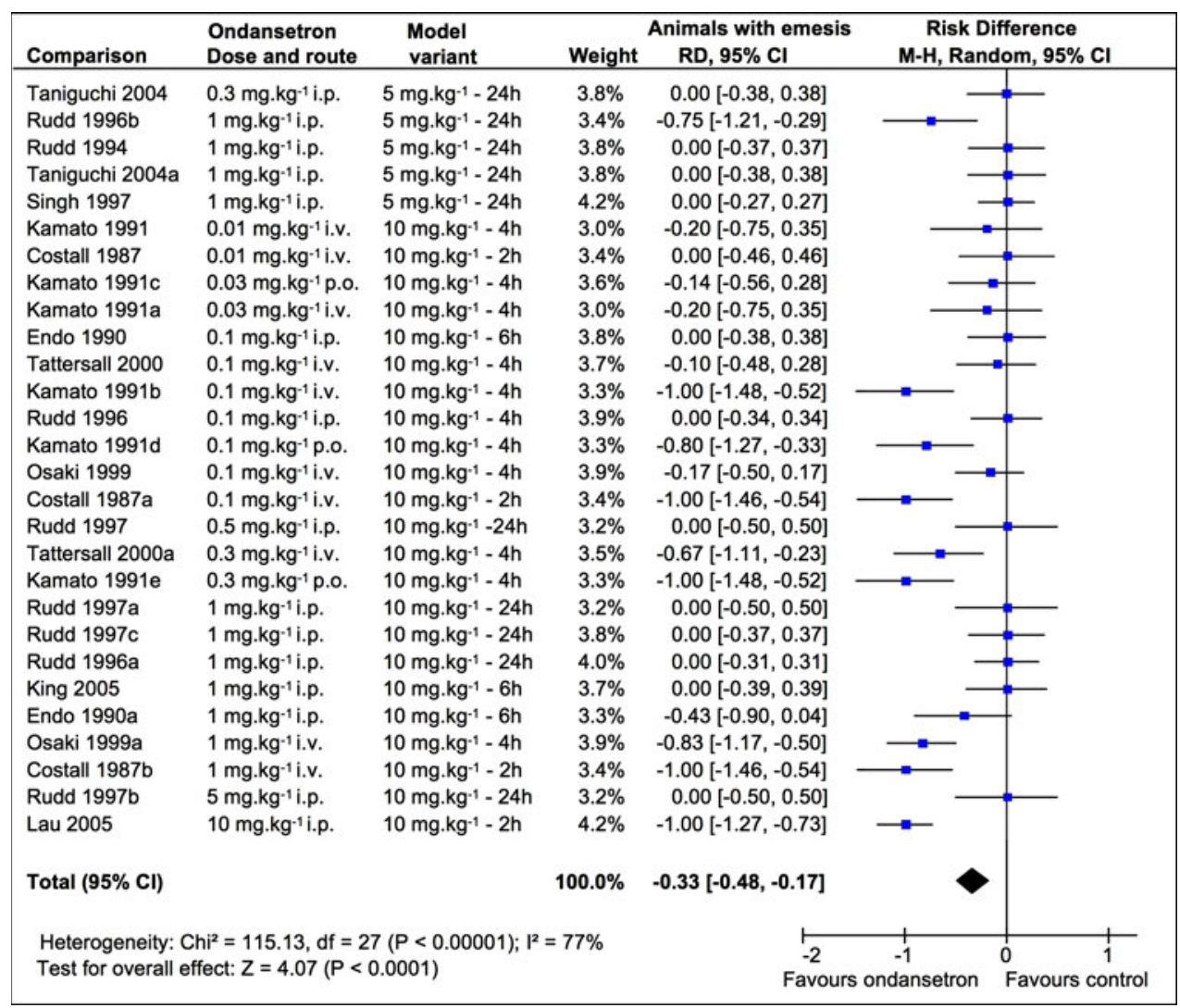

potentially be misleading as only 2 comparisons were included in that group and both reported the number of animals completely protected for $24 \mathrm{~h}$ in which setting none of the animals were completely protected (see Table 4, Fig. 5). The regimen used did not influence significantly the number of animals completely protected by ondansetron. There were no differences between the subgroup that received ondansetron at the time of cisplatin injection and the subgroups that received it $30 \mathrm{~min}$ and $1 \mathrm{~h}$ prior to cisplatin ( $Z$ tests, $P>0.05$ ) but once again, these results should be taken with caution as the heterogeneity within each subgroup was high. With longer observation times (24 h), ondansetron was equally ineffective given 2 or 3 times a day. Ondansetron appeared slightly more effective when cisplatin was injected i.v. compared to i.p. but this did not reach statistical significance $(Z=1.757, P=0.079)$ and could be biased by the fact that in all the comparisons where animals were observed for $24 \mathrm{~h}$, cisplatin was injected i.p. Furthermore, heterogeneity was, once again, highly significant in both groups (see Table 4). The origin of the animals and the quality score of the studies did not influence the effect of ondansetron ( $Z$ tests, $P>0.05$ ); however heterogeneity was high in all subgroups (see Table 4).

Outcome: latency Latency data was extracted from 10 full papers. Fifteen comparisons involving 131 ferrets assessed the effect of ondansetron on emesis induced by $10 \mathrm{mg} \mathrm{kg}^{-1}$ cisplatin and 3 comparisons assessed the effect of ondansetron on the latency to the onset of emesis induced by $5 \mathrm{mg} \mathrm{kg}^{-1}$ cisplatin (see Fig. 6). The global estimate of the effect of ondansetron on the latency was $0.86(0.49-1.24)$, which means that the latency was nearly twice as long in the groups treated with ondansetron compared to the control groups. This effect was significant $(Z=4.45, P<0.001)$ but $\chi^{2}$ test revealed a high degree of heterogeneity $\left(\chi^{2}=314.35, d f=14, P<0.001\right)$, which was corroborated by the $I^{2}(96 \%)$. Subgroup analysis revealed that ondansetron statistically delayed the latency to the onset of emesis induced by $10 \mathrm{mg} \mathrm{kg}^{-1}$ cisplatin but not $5 \mathrm{mg} \mathrm{kg}^{-1}$ cisplatin (Table 5, Fig. 6). The effect of ondansetron was dose dependant and doses of $1 \mathrm{mg} \mathrm{kg}^{-1}$ conferred a significantly higher protection, increasing the latency by about $200 \%$ ( $Z$ tests, $P<0.05$ ). Ondansetron was more effective when given i.p. than p.o. or i.v. ( $Z$ tests, $P<0.05$ ); however, this result needs to be taken with caution as ondansetron was injected i.p. in all the comparisons where the highest dose was given (see Fig. 6). No significant differences were observed with different treatment times, there was no difference in outcome if cisplatin was injected i.p. or i.v. and the origin of the ferrets did not influence the outcome ( $Z$ tests, $P>0.05)$. The outcome was not influenced by the quality of the study (see Table 1) as no 
Table 4 Sensitivity analyses of the effect of ondansetron on the number of animals with emesis following the administration of cisplatin (5 or $10 \mathrm{mg} \mathrm{kg}^{-1}$ )

\begin{tabular}{|c|c|c|c|c|c|}
\hline & $\begin{array}{l}\text { Effect estimate } \\
\text { (proportion of } \\
\text { ferrets with emesis) }\end{array}$ & $95 \% \mathrm{CI}$ & $\begin{array}{l}\text { Number of } \\
\text { comparisons }\end{array}$ & $\begin{array}{l}\text { Overall effect } \\
(Z \text { tests) }\end{array}$ & $\begin{array}{l}\text { Heterogeneity } \\
\left(\chi^{2}\right)\end{array}$ \\
\hline \multicolumn{6}{|c|}{ Cisplatin dose and duration of the observation period } \\
\hline $5 \mathrm{mg} / \mathrm{kg}(24 \mathrm{~h})$ & 0.00 & -0.15 to 0.15 & 5 & $P=1.000$ & $P=1.000$ \\
\hline $10 \mathrm{mg} / \mathrm{kg}(24 \mathrm{~h})$ & 0.00 & -0.23 to 0.23 & 4 & $P=1.000$ & $P=1.000$ \\
\hline $10 \mathrm{mg} / \mathrm{kg}(6 \mathrm{~h})$ & -0.11 & -0.38 to 0.15 & 3 & $P=0.400$ & $P=0.280$ \\
\hline $10 \mathrm{mg} / \mathrm{kg}(4 \mathrm{~h})$ & -0.48 & -0.70 to -0.26 & 12 & $P<0.001 * * *$ & $P<0.001 * * *$ \\
\hline $10 \mathrm{mg} / \mathrm{kg}(2 \mathrm{~h})$ & -0.76 & -1.21 to -0.31 & 4 & $P=0.001 * *$ & $P=0.002^{* *}$ \\
\hline \multicolumn{6}{|l|}{ Ondansetron dose } \\
\hline $0.01-0.03 \mathrm{mg} \mathrm{kg}^{-1}$ & -0.13 & -0.37 to 0.12 & 4 & $P=0.31$ & $P=0.93$ \\
\hline $0.1-0.5 \mathrm{mg} \mathrm{kg}^{-1}$ & -0.39 & -0.68 to -0.11 & 10 & $P=0.006^{* *}$ & $P<0.001 * * *$ \\
\hline $1-10 \mathrm{mg} \mathrm{kg}^{-1}$ & -0.33 & -0.57 to -0.10 & 14 & $P=0.006^{* *}$ & $P<0.001 * * *$ \\
\hline \multicolumn{6}{|c|}{ Mode of delivery of ondansetron } \\
\hline i.v. & -0.49 & 0.25 to 0.73 & 12 & $P<0.001 * * *$ & $P<0.001 * * *$ \\
\hline i.p. & -0.14 & -0.10 to 0.38 & 11 & $P=0.25$ & $P<0.001 * * *$ \\
\hline s.c. & -0.00 & -0.27 to 0.27 & 2 & $P=1.000$ & $P=1.000$ \\
\hline p.o. & -0.64 & -1.16 to -0.11 & 3 & $P=0.020^{*}$ & $P=0.020^{*}$ \\
\hline \multicolumn{6}{|l|}{ Treatment time } \\
\hline With cisplatin & -0.43 & -0.68 to -0.18 & 13 & $P<0.001 * * *$ & $P<0.001 * * *$ \\
\hline $30 \mathrm{~min}$ before & -0.29 & -0.60 to 0.02 & 6 & $P=0.060$ & $P=0.020^{*}$ \\
\hline $1 \mathrm{~h}$ before & -0.64 & -1.16 to -0.11 & 3 & $P=0.020^{*}$ & $P=0.020^{*}$ \\
\hline Twice daily & 0.00 & -0.27 to 0.27 & 2 & $P=1.000$ & $P=1.000$ \\
\hline Three times daily & 0.00 & -0.16 to 0.16 & 4 & $P=1.000$ & $P=1.000$ \\
\hline \multicolumn{6}{|c|}{ Mode of administration of cisplatin } \\
\hline i.v. & -0.49 & -0.73 to -0.25 & 12 & $P<0.001 * * *$ & $P<0.001 * * *$ \\
\hline i.p. & -0.21 & -0.41 to -0.01 & 16 & $P=0.04^{*}$ & $P<0.001 * * *$ \\
\hline \multicolumn{6}{|l|}{ Animal origin } \\
\hline UK & -0.24 & -0.43 to -0.04 & 14 & $P=0.020^{*}$ & $P<0.001 * * *$ \\
\hline USA & -0.36 & -0.57 to -0.14 & 13 & $P=0.001 * *$ & $P<0.001 * * *$ \\
\hline $\mathrm{NZ}$ & 1.00 & -1.27 to -0.73 & 1 & $P<0.001 * * *$ & N/A \\
\hline \multicolumn{6}{|l|}{ Quality score } \\
\hline Less that $5 / 9$ & -0.23 & -0.62 to 0.16 & 3 & $P=0.250$ & $P=0.030^{*}$ \\
\hline 5 to $7 / 9$ & -0.44 & -0.66 to -0.22 & 15 & $P<0.001 * * *$ & $P<0.001 * * *$ \\
\hline 7.5 to $9 / 9$ & -0.18 & -0.46 to 0.09 & 10 & $P=0.19$ & $P<0.001 * * *$ \\
\hline
\end{tabular}

The effect estimate was computed as the risk difference $(\mathrm{RD})$ and represents the proportion of animals with emesis during the duration of the observation period. An effect estimate of 0 indicates that the treatment had no effect on the number of animals with emesis, -1 indicates maximal effect. The variables examined were the variant of the cisplatin model ( 5 or $10 \mathrm{mg} \mathrm{kg}^{-1}$ cisplatin and the duration of the observation period), the mode of administration of cisplatin, the dose of ondansetron, the regimen of ondansetron administration (mode of delivery and timing relative to cisplatin administration), the animal origin (country animals were bred) and the quality score assigned to the study where comparisons were extracted

differences were detected between studies scoring less than 5 out of 9 , between 5 and $7 / 9$ and 7.5 or higher $(Z$ tests, $P>0.05)$.

Funnel plots for the effect of ondansetron on the $\mathrm{R}+\mathrm{V}$ and the number of animals with emesis were relatively symmetrical (see Fig. 7). The funnel plot for the latency was slightly asymmetrical, which reflects the high degree of heterogeneity detected for this outcome. Overall, no associations between treatment effect and sample size were detected, suggesting no evidence of publication bias.

Effect of $5-\mathrm{HT}_{3}$ receptor antagonists on the latency to the onset of emesis induced by $10 \mathrm{mg} \mathrm{kg}^{-1}$ cisplatin

The effects of 5-HT $\mathrm{H}_{3}$ receptor antagonists on the latency to the onset of $10 \mathrm{mg} / \mathrm{kg}$ cisplatin-induced emesis were 


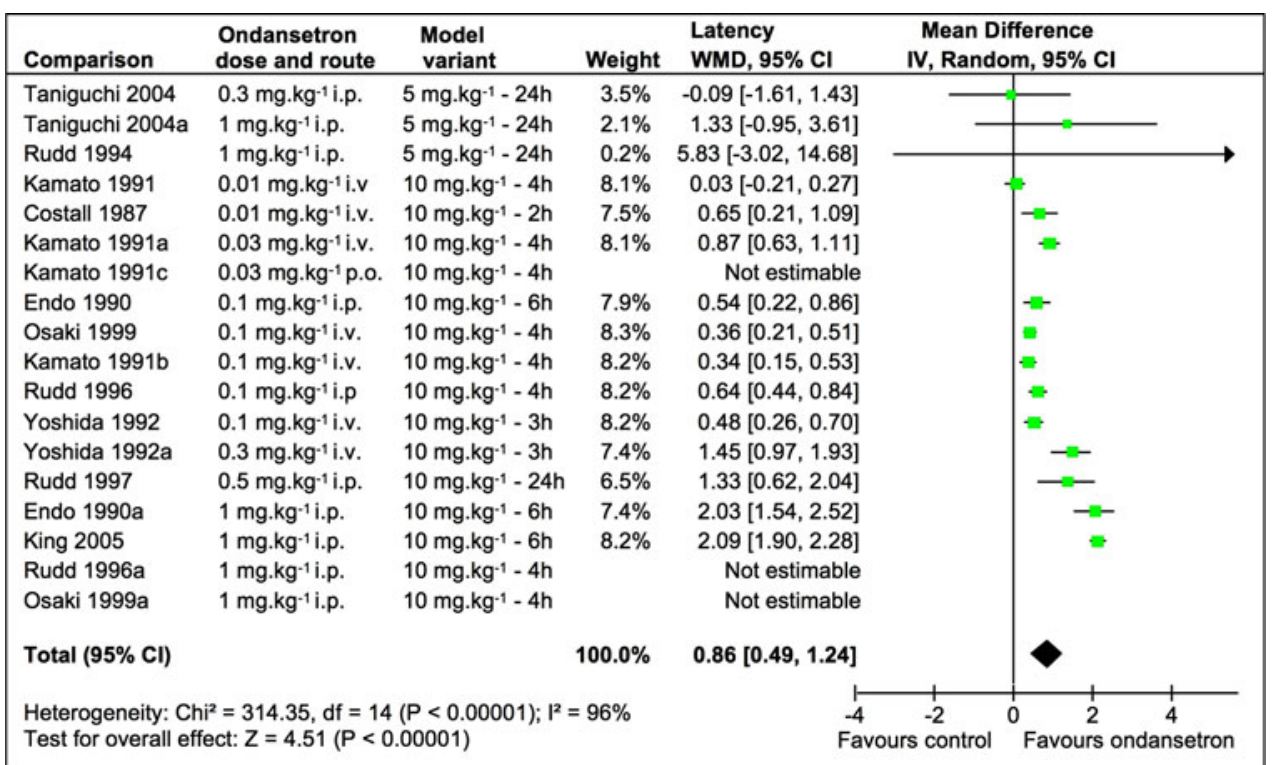

Fig. 6 Efficacy of ondansetron on the latency to emesis induced by cisplatin $\left(5\right.$ or $\left.10 \mathrm{mg} \mathrm{kg}^{-1}\right)$. Point estimates and $95 \%$ confidence intervals for each of the ondansetron versus control comparisons ranked by dose. The effect estimate is the impact of the treatment on the latency expressed as a proportion of the latency in the control group. An effect estimate $<0$ indicates that the latency was shorter in the control group

investigated with 11 different anti-emetics (ondansetron, granisetron, tropisetron, indisetron, dolasetron, L-683,877, renzapride, zacopride, bemesetron, azasetron and ramosetron), this data was extracted from 22 studies; 76 comparisons were reported, involving 587 ferrets. However, for 14 comparisons, because only one animal developed emesis in the treatment group, the point estimate and confidence interval could not be computed and was therefore not included in the calculation of the effect estimate. Altogether, $5-\mathrm{HT}_{3}$ receptor antagonists increased the latency by $72 \%$ (effect estimate: $0.72,95 \%$ CI $0.56-0.87$ ); this effect was highly significant $(Z=9.08, P<0.0001)$ but a high degree of heterogeneity $\left(\chi^{2}=1001.57, d f=61, P<0.0001\right.$, $\left.I^{2}=93.9 \%\right)$ was detected. Dolasetron $(0.02,-0.76$ to 0.80$)$ renzapride $(1.11,-0.18$ to 2.40$)$, bemesetron $(0.29,-0.17$ to 120$)$ and ramosetron $(0.19,-0.02$ to 0.39$)$ did not delay the onset of emesis in a statistically significant manner ( $Z$ tests, $P>0.05)$, whereas ondansetron $(0.88,0.49-1.27)$, granisetron $(0.67,0.41-0.93)$, tropisetron $(0.49,0.17-0.81)$, indisetron (0.92, 0.28-1.57), L-683,877 (0.72, 0.11-1.33), zacopride $(0.79,0.37-1.20)$ and azasetron $(0.52,0.37-0.67)$ significantly increased the latency by $49-92 \%$ ( $Z$ tests, $P<0.05)$.

\section{Effect of 5-HT $\mathrm{T}_{3}$ receptor antagonists on the acute and delayed phases of emesis induced by $5 \mathrm{mg} \mathrm{kg}^{-1}$ cisplatin}

Data for the effects of $5-\mathrm{HT}_{3}$ receptor antagonists on the daily emetic response induced by $5 \mathrm{mg} \mathrm{kg}^{-1}$ i.p. cisplatin than in the treatment group, 0 indicates that the treatment had no effect on the latency and an effect estimate of 1 indicates that the treatment increased the latency by $100 \%$. The size of each square represents the weight of the comparison in the WMD calculation. Note that in 3 comparisons, the effect estimate was not estimable as only one animal developed emesis in the group treated with ondansetron

were extracted from 5 studies; 8 comparisons were identified, involving 72 animals. 5- $\mathrm{HT}_{3}$ receptor antagonists reduced the number of $\mathrm{R}+\mathrm{V}$ by $68 \%(-0.68,-0.91$ to $-0.45)$ on day $1,67 \%(-0.67,-0.86$ to -0.48$)$ on day 2 and $53 \%(-0.53,-0.85$ to -0.38$)$ on day 3 ; this was statistically significant on each of the 3 days $(Z=5.74, Z=6.81$ and $Z=4.44$ for day 1, 2 and 3, respectively; $P<0.0001$, see Fig. 8). There was no difference between the effect of $5-\mathrm{HT}_{3}$ receptor antagonists on each of the 3 days ( $Z$ tests, $P>0.05)$; no statistical heterogeneity was detected $\left(\chi^{2}\right.$ tests, $P>0.05$ and $I^{2}=0 \%$ on each of the 3 days). The effects of granisetron and ondansetron were significant for each of the 3 days, whereas indisetron did significantly reduce the $\mathrm{R}+\mathrm{V}$ during day 1 and 3 but not day 2 . No significant differences were detected between the effects of ondansetron, granisetron and indisetron for each of the 3 days ( $Z$ tests, $P>0.05$ ).

\section{Discussion and conclusions}

Cisplatin-induced emesis in the ferret

We found that the latency to the onset of the cisplatininduced emesis was dose dependent, which is consistent with findings in other species such as humans [71], dogs [10] and pigeons [106]. A step-change was observed between 5 and $6 \mathrm{mg} \mathrm{kg}^{-1}$, suggesting a difference in the mechanisms triggering emesis at low and high dose, 
Table 5 Sensitivity analyses of the effect of ondansetron on the latency to the onset of emesis induced by cisplatin $\left(5 \mathrm{or}^{10} \mathrm{mg} \mathrm{kg}^{-1}\right)$

\begin{tabular}{|c|c|c|c|c|c|}
\hline & $\begin{array}{l}\text { Effect estimate } \\
\text { (proportion of } \\
\text { latency change) }\end{array}$ & $95 \% \mathrm{CI}$ & $\begin{array}{l}\text { Number of } \\
\text { comparisons }\end{array}$ & $\begin{array}{l}\text { Overall effect } \\
(Z \text { tests })\end{array}$ & $\begin{array}{l}\text { Heterogeneity } \\
\left(\chi^{2}\right)\end{array}$ \\
\hline \multicolumn{6}{|l|}{ Cisplatin dose } \\
\hline $10 \mathrm{mg} \mathrm{kg}^{-1}$ & 0.88 & 0.49 to 1.27 & 15 & $P<0.001 * * *$ & $P<0.001 * * *$ \\
\hline $5 \mathrm{mg} \mathrm{kg}^{-1}$ & 0.60 & -0.97 to 2.16 & 3 & $P=0.45$ & $P=0.29$ \\
\hline \multicolumn{6}{|l|}{ Ondansetron dose } \\
\hline $0.01-0.02 \mathrm{mg} \mathrm{kg}^{-1}$ & 0.36 & 0.00 to 0.72 & 3 & $P=0.050$ & $P=0.008^{* *}$ \\
\hline $0.03-0.06 \mathrm{mg} \mathrm{kg}^{-1}$ & 0.85 & 0.30 to 1.40 & 3 & $P=0.002 * *$ & $P<0.001 * * *$ \\
\hline $0.1 \mathrm{mg} \mathrm{kg}^{-1}$ & 0.49 & 0.31 to 0.67 & 5 & $P<0.001 * * *$ & $P=0.140$ \\
\hline $1 \mathrm{mg} \mathrm{kg}^{-1}$ & 1.96 & 1.66 to 2.25 & 7 & $P<0.001 * * *$ & $P=0.27$ \\
\hline \multicolumn{6}{|l|}{ Mode of delivery of ondansetron } \\
\hline i.v. & 0.60 & 0.35 to 0.85 & 9 & $P<0.001 * * *$ & $P<0.001 * * *$ \\
\hline p.o. & 0.34 & 0.15 to 0.53 & 2 & $P<0.001 * * *$ & N/A \\
\hline i.p. & 1.54 & 0.67 to 2.41 & 5 & $P<0.001 * * *$ & $P<0.001 * * *$ \\
\hline s.c. & 0.36 & -0.94 to 1.65 & 2 & $P=0.59$ & $P=0.31$ \\
\hline \multicolumn{6}{|l|}{ Treatment time } \\
\hline With cisplatin & 0.62 & 0.34 to 0.68 & 6 & $P<0.001 * * *$ & $P=0.010^{*}$ \\
\hline 20-30 min before & 1.11 & 0.25 to 1.96 & 5 & $P=0.010^{* *}$ & $P<0.001 * * *$ \\
\hline $1 \mathrm{~h}$ before & 0.34 & 0.15 to 0.53 & 2 & $P=0.010^{* *}$ & N/A \\
\hline $30 \mathrm{~min}$ before and $45 \mathrm{~min}$ after & 0.94 & -0.01 to 1.89 & 2 & $P=0.050^{*}$ & $P<0.001 * * *$ \\
\hline Twice daily & 0.36 & -0.94 to 1.65 & 2 & $P=0.590$ & $P=0.310$ \\
\hline Three times daily & 5.83 & -3.02 to 14.68 & 1 & $P=0.020^{*}$ & N/A \\
\hline \multicolumn{6}{|l|}{ Mode of administration of cisplatin } \\
\hline i.v. & 0.60 & 0.35 to 0.85 & 9 & $P<0.001 * * *$ & $P<0.001 * * *$ \\
\hline i.p. & 1.16 & 0.35 to 1.96 & 9 & $P=0.005$ & $P<0.001 * * *$ \\
\hline \multicolumn{6}{|l|}{ Animal origin } \\
\hline UK & 0.76 & 0.44 to 1.07 & 5 & $P<0.001 * * *$ & $P=0.19$ \\
\hline USA & 0.86 & 0.39 to 1.33 & 13 & $P<0.001 * * *$ & $P<0.001 * * *$ \\
\hline \multicolumn{6}{|l|}{ Quality score } \\
\hline Less that $5 / 9$ & 0.94 & -0.01 to 1.89 & 2 & $P=0.050$ & $P<0.001 * * *$ \\
\hline 5 to $7 / 9$ & 0.63 & 0.32 to 0.94 & 11 & $P<0.001 * * *$ & $P<0.001 * * *$ \\
\hline 7.5 to $9 / 9$ & 1.42 & 0.31 to 2.53 & 5 & $P=0.01 * *$ & $P<0.001 * * *$ \\
\hline
\end{tabular}

The effect estimate was computed as the weighted mean difference (WMD) and represents the impact of the treatment on the latency expressed as a proportion of the latency in the control group. An effect estimate $<0$ indicates that the latency was shorter in the control group than in the treatment group, 0 indicates that the treatment had no effect on the latency and an effect estimate of 1 indicates that the treatment increased the latency by $100 \%$. The variables examined were the dose and mode of administration of cisplatin, the dose of ondansetron, the regimen of ondansetron administration (mode of delivery and timing relative to cisplatin administration), the animal origin (country animals were bred) and the quality score assigned to the study where comparisons were extracted

possibly the activation of an additional mechanism (e.g. recruitment of less sensitive vagal afferent branches, area postrema). Prior anaesthesia and the route of administration of cisplatin were identified as confounding factors; the emetic response was also modulated by some of the vehicles used and factors inherent to the ferrets such as strain and origin. The difference between intravenous and intraperitoneal cisplatin may only reflect prior anaesthesia, as these two factors were dependent in the present study. Certainly, anaesthesia had an impact in its own right as differences were detected between injectable and volatile anaesthetics. The impact of the ferrets' origin could reflect a genuine difference between populations of ferrets but it might also indicate differences between laboratories rather than a difference between animals; this cannot be determined from the present study.

These findings however stress the relevance of choosing appropriate controls (e.g. vehicle control, sham-operated) and homogeneous groups of animals when using the ferret cisplatin model of emesis. 

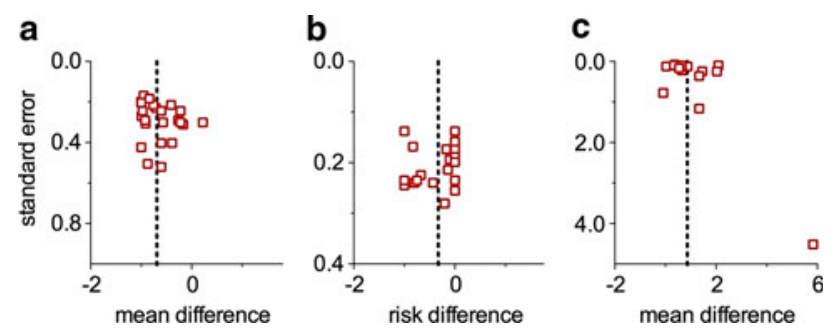

Fig. 7 Funnel plots for the effect of ondansetron on the number of retches + vomits (a), number of animals with emesis (b) and latency (c). For each comparison, the effect estimates are plotted on the $x$-axis and corresponding standard errors are plotted on the $y$-axis

The profile of emesis induced by $5 \mathrm{mg} \mathrm{kg}^{-1}$ i.p. cisplatin in the ferret was clearly biphasic, which is consistent with the profile of emesis observed in the clinic [84] but differences were observed in the timing and magnitude of the two phases. Whereas the acute phase is more severe than the delayed phase in humans $[72,84]$, with an onset $1-6 \mathrm{~h}$ following cisplatin infusion $[55,71,84]$, the latency to the onset of the acute phase was greater in the ferret $(>10 \mathrm{~h})$ and its relative intensity compared to the delayed phase was lower. The incidence of emesis on each day could not be investigated in the ferret as all reports stated that $100 \%$ of the animals developed an emetic response but no distinction was made between the acute and delayed phases. A few studies have however suggested that the acute phase was not observed in all animals [115, 147], which is also consistent with our recent observations [104] and suggests that whereas the incidence of emesis during the delayed phase is close to $100 \%$, the incidence of acute emesis at this dose is lower. In humans treated with placebo anti-emetics, however, the incidence of emesis during the acute phase (98\%, [71]) is higher than during the delayed phase $(44-89 \%[43,72])$.

\section{Effect of $5-\mathrm{HT}_{3}$ receptor antagonists}

The efficacy of ondansetron in the acute model of cisplatininduced emesis was assessed measuring 3 outcomes: the
Fig. 8 Efficacy of 5-HT 3 receptor antagonists on the daily number of retches + vomits $(\mathrm{R}+\mathrm{V})$ induced by $5 \mathrm{mg} \mathrm{kg}^{-1}$ i.p. cisplatin during the acute (day 1 ) and delayed (days 2,3) phases of emesis. Point estimates and $95 \%$ confidence intervals for each of the $5-\mathrm{HT}_{3}$ receptor antagonist versus control comparisons ranked by dose. The effect estimate was computed as the weighted mean difference $(W M D)$ and expressed as the proportion of retches and vomits in the control group. An effect estimate of -1 indicates that emesis was abolished in the treatment group, 0 indicates that the treatment had no effect on the $\mathrm{R}+\mathrm{V}$ response and an effect estimate $>0$ indicates that the treatment increased the number of $\mathrm{R}+\mathrm{V}$. The size of each square represents the weight of the comparison in the WMD calculation

\begin{tabular}{|c|c|c|c|c|c|c|}
\hline \multirow{2}{*}{$\frac{\text { Comparison }}{\text { day } 1}$} & \multirow[t]{2}{*}{ Drug } & \multirow[t]{2}{*}{$\begin{array}{c}\text { 5-HT } \mathrm{H}_{3} \mathrm{RA} \\
\text { Dose and route }\end{array}$} & \multirow[t]{2}{*}{ Weight } & \multirow[t]{2}{*}{$\begin{array}{l}\text { R+V } \\
\text { WMD, } 95 \% \mathrm{Cl}\end{array}$} & \multicolumn{2}{|c|}{$\begin{array}{c}\text { Mean Difference } \\
\text { IV, Random, } 95 \% \mathrm{Cl}\end{array}$} \\
\hline & & & & & & \\
\hline Taniguchi 2004 & indisetron & 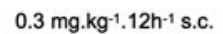 & $0.7 \%$ & $-0.74[-1.96,0.48]$ & & 6 \\
\hline Taniguchi 2004b & ondansetron & $0.3 \mathrm{mg}^{2} \mathrm{~kg}^{-1} .12 \mathrm{~h}^{-1}$ s.c. & $0.7 \%$ & $-0.60[-1.83,0.63]$ & & \\
\hline Rudd 1996 & ondansetron & $1 \mathrm{mg}^{-\mathrm{kg}^{-1} .8 \mathrm{~h}^{-1} \mathrm{i} . \mathrm{p} .}$ & $1.8 \%$ & $-0.60[-1.39,0.19]$ & $\longrightarrow$ & \\
\hline Fukunaka 1998 & granisetron & $1 \mathrm{mg} \mathrm{kg}^{-1} .8 \mathrm{~h}^{-1}$ i.p. & $3.5 \%$ & $-0.97[-1.53,-0.41]$ & - & \\
\hline Rudd 1994 & ondansetron & $1 \mathrm{mg}^{\mathrm{kg}} \mathrm{g}^{-1} .8 \mathrm{~h}^{-1}$ i.p & $6.2 \%$ & $-0.76[-1.18,-0.34]$ & 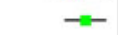 & \\
\hline Singh 1997 & ondansetron & $1 \mathrm{mg}^{\mathrm{kg}} \mathrm{g}^{-1} .8 \mathrm{~h} \mathrm{~h}^{-1} \mathrm{i} . \mathrm{p}$ & $6.3 \%$ & $-0.41[-0.83,0.01]$ & $-=$ & \\
\hline Taniguchi 2004a & indisetron & $1 \mathrm{mg}^{1 . \mathrm{kg}^{-1} \cdot 12 \mathrm{~h}^{-1} \text { s.c. }}$ & $0.7 \%$ & $-0.85[-2.08,0.38]$ & & \\
\hline $\begin{array}{l}\text { Taniguchi } 2004 \mathrm{c} \\
\text { Subtotal }(95 \% \mathrm{Cl})\end{array}$ & ondansetron & $1 \mathrm{mg}^{-k^{-1} \cdot 12 \mathrm{~h}^{-1} \mathrm{~s} . \mathrm{c} .}$ & $\begin{array}{r}0.8 \% \\
20.7 \%\end{array}$ & $\begin{array}{r}-0.87[-2.08,0.34] \\
-0.68[-0.91,-0.45]\end{array}$ & $\bullet$ & \\
\hline \multirow{2}{*}{\multicolumn{7}{|c|}{$\begin{array}{l}\text { Heterogeneity: } \mathrm{Ch}^{2}=3.00, \mathrm{df}=7(P=0.89) ; \mathrm{I}^{2}=0 \% \\
\text { Test for overall effect: } Z=5.74(P<0.00001)\end{array}$}} \\
\hline & & & & & & \\
\hline \multicolumn{7}{|l|}{ day 2} \\
\hline Taniguchi 2004 & indisetron & $0.3 \mathrm{mg} \cdot \mathrm{kg}^{-1} .12 \mathrm{~h}^{-1} \mathrm{~s} . \mathrm{c}$ & $0.8 \%$ & $-0.36[-1.57,0.85]$ & & \\
\hline Taniguchi 2004b & ondansetron & $0.3 \mathrm{mg}^{-\mathrm{kg}^{-1} .12 \mathrm{~h}^{-1} \mathrm{~s} . \mathrm{c}}$ & $0.6 \%$ & $-0.04[-1.36,1.28]$ & & \\
\hline Taniguchi 2004a & indisetron & $1 \mathrm{mg}^{-k^{-1}-12 \mathrm{~h}^{-1} \text { s.c. }}$ & $0.8 \%$ & $-0.75[-1.93,0.43]$ & & - \\
\hline Taniguchi $2004 \mathrm{c}$ & ondansetron & $1 \mathrm{mg}^{-\mathrm{kg}^{-1} \cdot 12 \mathrm{~h}^{-1} \text { s.c. }}$ & $0.7 \%$ & $-0.52[-1.76,0.72]$ & & \\
\hline Rudd 1996 & ondansetron & $1 \mathrm{mg} \mathrm{kg}^{-1} .8 \mathrm{~h}^{-1} 1$ i.p & $9.9 \%$ & $-0.84[-1.17,-0.51]$ & - & \\
\hline Rudd 1994 & ondansetron & $1 \mathrm{mg}^{\mathrm{kg}} \mathrm{kg}^{-1} .8 \mathrm{~h}^{-1} \mathrm{i} . \mathrm{p}$ & $6.0 \%$ & $-0.72[-1.15,-0.29]$ & $\rightarrow$ & \\
\hline Fukunaka 1998 & granisetron & $1 \mathrm{mg}^{\mathrm{kg}} \mathrm{kg}^{-1} .8 \mathrm{~h}^{-1}$ i.p & $2.8 \%$ & $-0.72[-1.35,-0.09]$ & $\longrightarrow$ & \\
\hline Singh 1997 & ondansetron & $1 \mathrm{mg}^{\mathrm{kg}} \mathrm{kg}^{-1} .8 \mathrm{~h}^{-1}$ i.p & $8.4 \%$ & $-0.49[-0.85,-0.13]$ & - & \\
\hline Subtotal (95\% Cl) & & & $30.0 \%$ & $-0.67[-0.86,-0.48]$ & $\bullet$ & \\
\hline \multirow{2}{*}{\multicolumn{7}{|c|}{ Heterogeneity: $\mathrm{Ch}^{2}=3.22, \mathrm{df}=7(\mathrm{P}=0.86) ; \mathrm{l}^{2}=0 \%$}} \\
\hline & & & & & & \\
\hline \multicolumn{7}{|l|}{ day 3} \\
\hline Taniguchi 2004 & indisetron & $0.3 \mathrm{mg} \cdot \mathrm{kg}^{-1} .12 \mathrm{~h}^{-1} \mathrm{~s} . \mathrm{c}$ & $0.9 \%$ & $-0.55[-1.67,0.57]$ & & \\
\hline Taniguchi 2004b & ondansetron & $0.3 \mathrm{mg}^{2} \mathrm{~kg}^{-1} .12 \mathrm{~h}^{-1} \mathrm{~s} . \mathrm{c}$ & $1.1 \%$ & $-0.35[-1.35,0.65]$ & - & \\
\hline Yamakuni 2006a & zacopride & $1 \mathrm{mg}^{\mathrm{kg}} \mathrm{kg}^{-1} .12 \mathrm{~h}^{-1} \mathrm{i} . \mathrm{v}$ & $2.5 \%$ & $-0.71[-1.38,-0.04]$ & & \\
\hline Taniguchi 2004a & indisetron & $1 \mathrm{mg}^{-k^{-1} \cdot 12 \mathrm{~h}^{-1} \text { s.c. }}$ & $1.1 \%$ & $-1.00[-1.98,-0.02]$ & & \\
\hline Taniguchi $2004 \mathrm{c}$ & ondansetron & $1 \mathrm{mg}^{1} \mathrm{~kg}^{-1} .12 \mathrm{~h}^{-1}$ s.c. & $1.1 \%$ & $-0.47[-1.48,0.54]$ & & \\
\hline Rudd 1996 & ondansetron & 1 mg.kg-1. $.8 \mathrm{~h}^{-1}$ i.p. & $4.3 \%$ & $-0.38[-0.89,0.13]$ & - & \\
\hline Rudd 1994 & ondansetron & $1 \mathrm{mg} \cdot \mathrm{kg}^{-1} .8 \mathrm{~h}^{-1} 1$ i.p. & $4.5 \%$ & $-0.73[-1.23,-0.23]$ & 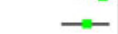 & \\
\hline Fukunaka 1998 & granisetron & $1 \mathrm{mg} \mathrm{kg}^{-1} .8 \mathrm{~h}^{-1}$ i.p. & $3.2 \%$ & $-0.71[-1.29,-0.13]$ & $\longrightarrow$ & \\
\hline Singh 1997 & ondansetron & 1 mg.kg-1. $.8 \mathrm{~h}^{-1}$ i.p. & $15.0 \%$ & $-0.24[-0.51,0.03]$ & -1 & \\
\hline Nakayama 2005 & granisetron & $3.2 \mathrm{mg}^{\mathrm{kg}} \mathrm{kg}^{-1} .8 \mathrm{~h}^{-1} \mathrm{i} . \mathrm{v} .$. & $6.4 \%$ & $-0.75[-1.17,-0.33]$ & $=$ & \\
\hline Nakayama 2005a & FK1052 & 3.2 mg.kg-1. $.8 \mathrm{~h}^{-1} \mathrm{i} . \mathrm{v}$. & $6.6 \%$ & $-0.76[-1.17,-0.35]$ & $=$ & \\
\hline Yamakuni 2006 & granisetron & 3.2 mg.kg-1. $8 \mathrm{~h}^{-1} \mathrm{i} . v$. & $2.7 \%$ & $-0.43[-1.07,0.21]$ & - & \\
\hline Subtotal $(95 \% \mathrm{Cl})$ & & & $49.3 \%$ & $-0.53[-0.68,-0.38]$ & $\diamond$ & \\
\hline \multicolumn{7}{|c|}{$\begin{array}{l}\text { Heterogeneity: Chi } i^{2}=9.38, d f=11(P=0.59) ; l^{2}=0 \% \\
\text { Test for overall effect: } Z=6.91(P<0.00001)\end{array}$} \\
\hline \multicolumn{3}{|l|}{ Total $(95 \% \mathrm{Cl})$} & $100.0 \%$ & $-0.60[-0.71,-0.50]$ & 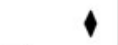 & \\
\hline \multicolumn{4}{|c|}{ Heterogeneity: $C \mathrm{~h}^{2}=17.39, \mathrm{df}=27(\mathrm{P}=0.92) ; \mathrm{I}^{2}=0 \%$} & & $\begin{array}{c}1 \\
-2\end{array}$ & $\frac{1}{2}$ \\
\hline \multicolumn{4}{|c|}{ Test for overall effect: $Z=11.20(P<0.00001)$} & Favour & 5HT3RAs & Favours control \\
\hline
\end{tabular}


number of $\mathrm{R}+\mathrm{V}$, the number of animals with emesis and the latency to the onset of emesis. Overall, all 3 outcomes permitted the detection of significant anti-emetic protection, which is consistent with findings in humans [24], but different variants of the model resulted in different levels of antiemetic protection. Whereas all variants of the acute model reflected a similar reduction of $\mathrm{R}+\mathrm{V}$, ondansetron only delayed significantly the onset of emesis following 10 but not $5 \mathrm{mg} \mathrm{kg}^{-1}$ cisplatin, and the number of animals with emesis was only reduced with observation periods no longer than $4 \mathrm{~h}$. In the $10 \mathrm{mg} \mathrm{kg}^{-1} 4 \mathrm{~h}$ variant of the model, half of the animals were completely protected from emesis, which was comparable to percentage of patients free of emesis during the acute phase of high-dose $\left(>50 \mathrm{mg} \mathrm{m}^{-2}\right)$ cisplatin-induced emesis in human patients $[58,65,85$, 124]. Overall, the acute phase of emesis induced by $5 \mathrm{mg} \mathrm{kg}^{-1}$ cisplatin represented poorly the clinical situation and the $4 \mathrm{~h}$ to $10 \mathrm{mg} \mathrm{kg}^{-1}$ model was more predictive of cisplatin-induced emesis in humans.

Overall, $5-\mathrm{HT}_{3}$ receptor antagonists reduced the emetic response to the same extent during the acute and delayed phases, which contrasts with findings reported in the majority of clinical studies, describing limited or non-significant effect of $5-\mathrm{HT}_{3}$ receptor antagonists during the delayed phase $[57,73]$. This discrepancy may be explained by a difference in outcome usually measured in humans (daily incidence, percentage of patients developing emesis) and ferrets (severity, number of $\mathrm{R}+\mathrm{V}$ ). Even though daily incidence and severity (measured by visual analogue scale) of the delayed phase emesis appear to be positively correlated in the absence of anti-emetic therapy [72], they can be uncoupled following anti-emetic treatment and the number of emetic episodes may be reduced while the incidence remains unchanged [100]. Alternatively, it is conceivable that the delayed phase of emesis in the ferret is more sensitive to $5-\mathrm{HT}_{3}$ receptor antagonists than it is in humans. The latter would be consistent with a longer acute phase in the ferret (see [110] for details), implying that the mechanism regulating the acute phase (i.e. 5-HT-mediated activation of the abdominal vagal afferents) remains activated longer. The ferret model thus correctly identified the anti-emetic potential of $5-\mathrm{HT}_{3}$ receptor antagonists against both the acute and delayed phases of cisplatin-induced emesis, but the magnitude of the anti-emetic effect during the delayed phase appears greater in the ferret than it is in humans.

\section{Methodology}

In the present study, the methodology used in the metaanalysis of human clinical trials was modified and adapted to animal research, and several concessions had to be made. First of all, the criteria used to select studies for inclusion into the systematic review and meta-analysis, and assess quality, did not include randomization and blinding. Whereas these two parameters are considered essential for human clinical trials and it has been suggested that their absence favours positive findings in animal research [8], emesis is an objective measurement, which is not investigator-dependent and we have no reason to believe that the inclusion of such studies in our analysis biased our findings. Additionally, randomization and blinding in the identified studies were too rarely reported to be used as inclusion criteria. The exclusion criteria were chosen to ensure the collection of reliable, clearly defined data. The majority of excluded studies (see Table 2) were removed because emesis was not quantified as latency, retches, vomits and/or incidence. We chose not to include outcomes such as "emetic episodes" or "bouts of emesis" in the present analysis because of the disparity of definitions and possible interpretations. This may however restrict the conclusions of our study.

Secondly, whereas clinical trials usually report tens or hundreds of patients in each study arm, we found that in the cisplatin ferret model, typically 4 to 8 animals were allocated in each treatment group. This may limit the relevance of such an analysis, designed to compare much bigger samples. Additionally, because a majority of studies compared one control group to several treatment groups-typically different doses of a compound-in order to maintain the data from different doses as distinct comparisons, the number of animals in the control group was divided by the number of treatment groups it was compared to. The limitation of such an approach is that in the effect estimate calculation, the weight of such comparisons is reduced, which benefits comparisons extracted from studies that only compared one control group to one treatment group and is not justified by the quality of the studies.

\section{Conclusions}

We demonstrated the potential of a meta-analysis to address the 3R's (Replacement, Refinement and Reduction), developed by Russel and Burch as criteria for a humane use of animals in research [126]. By maximising the utilisation of animal data, thus extracting novel scientific information without increasing the number of animals, such analysis addresses Reduction, as this reduces the future use of animals. Additionally, the effects of ondansetron on the 3 outcomes highlighted a logical Refinement of the model by reducing the observation period. The cisplatin $10 \mathrm{mg} / \mathrm{kg}$ to $4 \mathrm{~h}$ variant of the model stands out as the most appropriate to study the acute phase of cisplatin-induced emesis, whereas $5 \mathrm{mg} / \mathrm{kg}$ to $24-72 \mathrm{~h}$ remains the model of choice to study cisplatin-induced delayed emesis.

The present study is a proof of concept. In an attempt to focus the scope of the analysis, it was limited to an animal 
model with one emetic: cisplatin, one species: the ferret and one class of anti-emetic drugs: $5-\mathrm{HT}_{3}$ receptor antagonists; the drugs investigated are already successfully used in humans against chemotherapy-induced emesis. Globally, the effects in the ferret were consistent with clinical findings, which were expected as they were originally developed in the ferret model; this demonstrates that a meta-analysis is an appropriate method to identify the anti-emetic potential of a drug and confirms that the ferret model of cisplatin-induced emesis is truly predictive and relevant to humans. This method can now be applied to investigate the effects of $\mathrm{NK}_{1}$ receptor antagonists, which were also developed using the ferret and which have recently been introduced into the clinic. However, recent studies suggest that there may be a discrepancy between the "broad spectrum" anti-emetic efficacy in the ferret and the efficacy in the clinic [3, 25]. This method can also be used in other "model" species (e.g. $\operatorname{dog}$ ) to reassess "older" compounds such as dopamine receptor antagonists or opioids, whose effects on cisplatininduced emesis are less well characterised. It can also be directly applied to other emetic models (different emetogen and/or different species) and adapted to assess the relevance of models arguably predictive of nausea and emesis such as pica in the rat and conditioned taste aversion $[2,77]$.

Acknowledgments The authors would like to thank Carol Kilkenny (NC3Rs), Fiona Reid (SGUL) and Toby Lasserson (SGUL) for statistical advice, and Dr John Watson (Pfizer, USA), Dr Masahiko Hirafuji (University of Hokkaido, Japan) and Dr Hisashi Yamakuni (Astellas Pharma Inc., Japan), who provided original data. NPdS was supported by a PhD studentship from Merck Research Laboratories.

Open Access This article is distributed under the terms of the Creative Commons Attribution Noncommercial License which permits any noncommercial use, distribution, and reproduction in any medium, provided the original author(s) and source are credited.

\section{References}

1. Altman DG (1991) Practical statistics for medical research. Chapman \& Hall, London

2. Andrews PLR, Horn CC (2006) Signals for nausea and emesis: implications for models of upper gastrointestinal diseases. Auton Neurosci 125:100-115

3. Andrews PLR, Rudd JA (2004) The role of tachykinins and the tachykinin NK1 receptor in nausea and emesis. In: Holzer P (ed) Handbook of experimental pharmacology. Springer, Berlin

4. Angel I, Schoemaker H, Prouteau M, Garreau M, Langer SZ (1993) Litoxetine: a selective 5-HT uptake inhibitor with concomitant 5-HT3 receptor antagonist and antiemetic properties. Eur J Pharmacol 232:139-145

5. Barnes JM, Barnes NM, Costall B, Naylor RJ, Tattersall FD (1988) Reserpine, para-chlorophenylalanine and fenfluramine antagonise cisplatin-induced emesis in the ferret. Neuropharmacology 27:783-790

6. Barnes NM, Barry JM, Costall B, Naylor RJ, Tattersall FD (1987) Antagonism by para-chlorophenylalanine of cisplatininduced emesis. Br J Pharmacol 92:649P
7. Barnes NM, Bunce KT, Naylor RJ, Rudd JA (1991) The actions of fentanyl to inhibit drug-induced emesis. Neuropharmacology 30:1073-1083

8. Bebarta V, Luyten D, Heard K (2003) Emergency medicine animal research: does use of randomization and blinding affect the results? Acad Emerg Med 10:684-687

9. Bermudez J, Boyle EA, Miner WD, Sanger GJ (1988) The antiemetic potential of the 5-hydroxytryptamine3 receptor antagonist BRL 43694. Br J Cancer 58:644-650

10. Bhandari P, Gupta YK, Seth SD, Chugh A (1988) Emetic profile of cisplatin in dogs. Asia Pac J Pharmacol 3:131-133

11. Bingham S, Blower PR, Davey PT, King PD, Sanger GJ, Wardle KA, Nishioka Y (1994) Differences between the anti-emetic efficacies of the 5-HT3 receptor antagonists Granisetron and Azasetron in the conscious ferret. Pharmacometrics 47:21-28

12. Blower PR (1990) The role of specific 5-HT3 receptor antagonism in the control of cytostatic drug-induced emesis. Eur J Cancer 26(Suppl 1):S8-S11

13. Blum E, Buchheit KH, Buecher HH, Gamse R, Kloeppner E, Meigel H, Papageorgiou C, Waelchli R, Revesz L (1992) Design and synthesis of novel ligands for the 5-HT4 and the 5-HT4 receptor. Bioorg Med Chem Lett 2:461-466

14. Borison HL, Wang SC (1953) Physiology and pharmacology of vomiting. Pharmacol Rev 5:193-230

15. Bountra C, Bunce K, Dale T, Gardner C, Jordan C, Twissell D, Ward P (1993) Anti-emetic profile of a non-peptide neurokinin NK1 receptor antagonist, CP-99, 994, in ferrets. Eur J Pharmacol 249:R3-R4

16. Chevalier E, Singh L, Diop L (1998) Anti-emetic effects of PD154075. Gastroenterology 114:A578

17. Clark RD, Miller AB, Berger J, Repke DB, Weinhardt KK, Kowalczyk BA, Eglen RM, Bonhaus DW, Lee CH, Michel AD et al (1993) 2-(Quinuclidin-3-yl)pyrido[4, 3-b]indol-1-ones and isoquinolin-1-ones. Potent conformationally restricted 5-HT3 receptor antagonists. J Med Chem 36:2645-2657

18. Costall B, Domeney AM, Gunning SJ, Kelly ME, Naylor RJ, Nohria V, Owera-Atepo JB, Simpson KM, Tan CC, Tattersall D (1987) The action of dazopride to enhance gastric emptying and block emesis. Neuropharmacology 26:669-677

19. Costall B, Domeney AM, Gunning SJ, Naylor RJ, Tattersall D, Tyers MB (1987) GR38032F: a potent and novel inhibitor of cisplatin-induced emesis in the ferret. Br J Pharmacol 90:90P

20. Costall B, Domeney AM, Naylor RJ, Owera-Atepo JB, Rudd JA, Tattersall FD (1990) Fluphenazine, ICS 205-930 and dl-fenfluramine differentially antagonise drug-induced emesis in the ferret. Neuropharmacology 29:453-462

21. Costall B, Domeney AM, Naylor RJ, Tattersall FD (1986) 5-Hydroxytryptamine M-receptor antagonism to prevent cisplatin-induced emesis. Neuropharmacology 25:959-961

22. Costall B, Domeney AM, Naylor RJ, Tattersall FD (1987) Emesis induced by cisplatin in the ferret as a model for the detection of anti-emetic drugs. Neuropharmacology 26:1321-1326

23. Costall B, Naylor RJ, Tattersall FD (1990) The actions of fenfluramine and interaction with 5-HT3 receptor-antagonists to inhibit emesis in the ferret. J Pharm Pharmacol 42:94-101

24. Cubeddu LX, Hoffmann IS, Fuenmayor NT, Finn AL (1990) Efficacy of ondansetron (GR 38032F) and the role of serotonin in cisplatin-induced nausea and vomiting. N Engl J Med 322:810-816

25. Dando TM, Perry CM (2004) Aprepitant: a review of its use in the prevention of chemotherapy-induced nausea and vomiting. Drugs 64:777-794

26. Davis CJ (1988) Neuropharmacological investigations into the mechanisms of emesis caused by cytotoxic drugs and radiation. Clinical pharmacology. Oxford University, $\mathrm{PhD}$ thesis

27. Delagrange P, Emerit MB, Merahi N, Abraham C, Morain P, Rault S, Renard P, Pfeiffer B, Guardiola-Lemaitre B, Hamon M 
(1996) Interaction of S 21007 with 5-HT3 receptors. In vitro and in vivo characterization. Eur J Pharmacol 316:195-203

28. DerSimonian R, Kacker R (2007) Random-effects model for meta-analysis of clinical trials: an update. Contemp Clin Trials 28:105-114

29. Eglen RM, Bonhaus DW, Clark RD, Johnson LG, Lee CH, Leung E, Smith WL, Wong EH, Whiting RL (1994) (R) and (S) RS 56532: mixed 5-HT3 and 5-HT4 receptor ligands with opposing enantiomeric selectivity. Neuropharmacology 33:515-526

30. Eglen RM, Lee CH, Smith WL, Johnson LG, Clark R, Whiting RL, Hegde SS (1995) Pharmacological characterization of RS 25259-197, a novel and selective 5-HT3 receptor antagonist, in vivo. Br J Pharmacol 114:860-866

31. Eglen RM, Lee CH, Smith WL, Johnson LG, Whiting RL, Hegde SS (1993) RS 42358-197, a novel and potent 5-HT3 receptor antagonist, in vitro and in vivo. J Pharmacol Exp Ther 266:535543

32. Endo T, Minami M, Monma Y, Saito H, Takeuchi M (1990) Emesis-related biochemical and histopathological changes induced by cisplatin in the ferret. J Toxicol Sci 15:235-244

33. Endo T, Minami M, Monma Y, Yoshioka M, Saito H, Kinami J, Toshimitsu Y, Parvez SH (1990) Effect of GR38032F on cisplatin- and cyclophosphamide-induced emesis in the ferret. Biog Amines 7:525-533

34. Endo T, Minami M, Monma Y, Yoshioka M, Saito H, Parvez SH (1992) Vagotomy and ondansetron (5-HT3 antagonist) inhibited the increase of serotonin concentration induced by cytotoxic drugs in the area postreama of ferrets. Biog amines 9:163-175

35. Endo T, Nemoto M, Minami M, Yoshioka M, Saito H, Parvez SH (1995) Changes in the afferent abdominal vagal nerve activity induced by cisplatin and copper sulfate in the ferret. Biog Amines 11:399-407

36. Endo T, Nemoto M, Monma Y, Hamaue N, Togashi M, Hirafuji M (1994) Combined effect of domperidone and granisetron on cisplatin-induced emesis in the ferret. Pharmacometrics 47:435442

37. European Medicines Agency (2006) Guideline on non-clinical and clinical development of medicinal products for the treatment of nausea and vomiting associated with cancer chemotherapy. CPMP/EWP/4937/03. In: EMEA (ed) London, UK

38. Fink-Jensen A, Judge ME, Hansen JB, Jacobsen P, Turski L, Olney J, Honore T (1992) Inhibition of cisplatin-induced emesis in ferrets by the non-NMDA receptor antagonists NBQX and CNQX. Neurosci Lett 137:173-177

39. Fitzpatrick LR, Lambert RM, Pendley CE, Martin GE, Bostwick JS, Gessner GW, Airey JE, Youssefyeh RD, Pendleton RG, Decktor DL (1990) RG 12915: a potent 5-hydroxytryptamine-3 antagonist that is an orally effective inhibitor of cytotoxic druginduced emesis in the ferret and dog. J Pharmacol Exp Ther 254:450-455

40. Florczyk AP, Schurig JE, Bradner WT (1982) Cisplatin-induced emesis in the Ferret: a new animal model. Cancer Treat Rep 66:187-189

41. Florczyk AP, Schurig JE, Lenaz L, Bradner WT (1981) the ferret: a new animal model of cis-platinum induced emesis. Proc Am Assoc Canc Res 22:228

42. Fukunaka N, Sagae S, Kudo R, Endo T, Hirafuji M, Minami M (1998) Effects of granisetron and its combination with dexamethasone on cisplatin-induced delayed emesis in the ferret. Gen Pharmacol 31:775-781

43. Gandara, Harvey WH, Monaghan GG, Perez EA, Hesketh PJ (1993) Delayed emesis following high-dose cisplatin: a doubleblind randomised comparative trial of ondansetron (GR 38032F) versus placebo. Eur J Cancer 29A(Suppl 1):S35-S38

44. Gardner CJ, Armour DR, Beattie DT, Gale JD, Hawcock AB, Kilpatrick GJ, Twissell DJ, Ward P (1996) GR205171: a novel antagonist with high affinity for the tachykinin NK1 receptor, and potent broad-spectrum anti-emetic activity. Regul Pept 65:45-53

45. Gardner CJ, Bountra C, Bunce KT, Dale TJ, Jordan CC, Twissell DJ, Ward P (1994) Anti-emetic activity of neurokinin NK1 receptor antagonists is mediated centrally. $\mathrm{Br} \mathrm{J}$ Pharmacol 112:516P

46. Gardner CJ, Twissell DJ, Dale TJ, Gale JD, Jordan CC, Kilpatrick GJ, Bountra C, Ward P (1995) The broad-spectrum anti-emetic activity of the novel non-peptide tachykinin NK1 receptor antagonist GR203040. Br J Pharmacol 116:3158-3163

47. Gonsalves S, Watson J, Ashton C (1996) Broad spectrum antiemetic effects of CP-122, 721, a tachykinin NK1 receptor antagonist, in ferrets. Eur J Pharmacol 305:181-185

48. Gooch CL, Boissonade FM, Grundy D (1998) Somatostatin analogue octreotide inhibits retching to cisplatin in anaesthetised ferret. Gastroenterology 114:A1147

49. Gylys JA, Wright RN, Nicolosi WD, Buyniski JP, Crenshaw RR (1988) BMY-25801, an antiemetic agent free of D2-dopamine receptor antagonist properties. J Pharmacol Exp Ther 244:830 837

50. Haga K, Inaba K, Shoji H, Morimoto Y, Fukuda T, Setoguchi M (1993) The effects of orally administered Y-25130, a selective serotonin3-receptor antagonist, on chemotherapeutic agent-induced emesis. Jpn J Pharmacol 63:377-383

51. Haga K, Inaba K, Syoji H (2000) The effect of azasetron hydrochloride (serotone (TM)) on delayed emesis induced by a chemotherapeutic agent, cisplatin. Jpn Pharmacol Ther 28:285-290

52. Hale JJ, Mills SG, MacCoss M, Dorn CP, Finke PE, Budhu RJ, Reamer RA, Huskey SE, Luffer-Atlas D, Dean BJ, McGowan EM, Feeney WP, Chiu SH, Cascieri MA, Chicchi GG, Kurtz MM, Sadowski S, Ber E, Tattersall FD, Rupniak NM, Williams AR, Rycroft W, Hargreaves R, Metzger JM, MacIntyre DE (2000) Phosphorylated morpholine acetal human neurokinin-1 receptor antagonists as water-soluble prodrugs. J Med Chem 43:1234-1241

53. Hale JJ, Mills SG, MacCoss M, Finke PE, Cascieri MA, Sadowski S, Ber E, Chicchi GG, Kurtz M, Metzger J, Eiermann G, Tsou NN, Tattersall FD, Rupniak NM, Williams AR, Rycroft W, Hargreaves R, MacIntyre DE (1998) Structural optimization affording 2-(R)-(1-(R)-3, 5-bis(trifluoromethyl)phenylethoxy)-3(S)-(4-fluoro)phenyl-4-(3-oxo-1, 2, 4-triazol-5-yl)methylmorpholine, a potent, orally active, long-acting morpholine acetal human NK-1 receptor antagonist. J Med Chem 41:4607-4614

54. Hargreaves R, Tattersall D, Rycroft W, Woodford K, Ladduwahetty T, Keown L, Merchant K, Swain C, MacLeod AM, Baker R, Francis B, Burns D, Cascieri M, Metzger J, MacIntyre DE, Williamson DJ, Iversen LL, Hill RG (1994) Evidence that the anti-emetic effects of NK1 receptor antagonists are centrally mediated. Can J Physiol Pharmacol 72(suppl 2):45

55. Harris AL, Cantwell BMJ (1986) Mechanisms and treatment of cytotoxic-induced nausea and vomiting. In: Davis CJ, LakeBakaar GV, Grahame-Smith DG (eds) Nausea and vomiting: mechanisms and treatment. Springer, Berlin, pp 78-93

56. Hawthorn J, Ostler KJ, Andrews PLR (1988) The role of the abdominal visceral innervation and 5-hydroxytryptamine M-receptors in vomiting induced by the cytotoxic drugs cyclophosphamide and cis-platin in the ferret. Q J Exp Physiol 73:7-21

57. Hesketh PJ (2005) Management of nausea and vomiting in cancer and cancer treatment. Jones and Barlett Publishers Inc., Sudbury

58. Hesketh PJ, Murphy WK, Lester EP, Gandara DR, Khojasteh A, Tapazoglou E, Sartiano GP, White DR, Werner K, Chubb JM (1989) GR 38032F (GR-C507/75): a novel compound effective in the prevention of acute cisplatin-induced emesis. J Clin Oncol 7:700-705

59. Higgins GA, Kilpatrick GJ, Bunce KT, Jones BJ, Tyers MB (1989) 5-HT3 receptor antagonists injected into the area 
postrema inhibit cisplatin-induced emesis in the ferret. Br J Pharmacol 97:247-255

60. Hollingworth GJ, Carlson EJ, Castro JL, Chicchi GG, Clark N, Cooper LC, Dirat O, Salvo JD, Elliott JM, Kilburn R, Kurtz MM, Rycroft W, Tattersall FD, Tsao KL, Swain CJ (2006) Novel lactam NK1 antagonists with anti-emetic activity. Bioorg Med Chem Lett 16:1197-1201

61. Holmes AM, Rudd JA, Tattersall FD, Aziz Q, Andrews PLR (2009) Opportunities for the replacement of animals in the study of nausea and vomiting. Br J Pharmacol 157:865-880

62. Horn J, de Haan RJ, Vermeulen M, Luiten PG, Limburg M (2001) Nimodipine in animal model experiments of focal cerebral ischemia: a systematic review. Stroke 32:2433-2438

63. Horn J, Limburg M (2001) Calcium antagonists for ischemic stroke: a systematic review. Stroke 32:570-576

64. Ito T, Yoshida N, Miura Y, Omoya H, Karasawa T (1990) Antiemetic effects of AS-5370, a novel serotonin 5-HT3 receptor antagonist. Eur J Pharmacol 183:1214-1215

65. Jantunen IT, Kataja VV, Muhonen TT (1997) An overview of randomised studies comparing 5-HT3 receptor antagonists to conventional anti-emetics in the prophylaxis of acute chemotherapy-induced vomiting. Eur J Cancer 33:66-74

66. Kamato T, Ito H, Nagakura Y, Nishida A, Yuki H, Yamano M, Miyata K (1993) Mechanisms of cisplatin- and m-chlorophenylbiguanide-induced emesis in ferrets. Eur J Pharmacol 238:369376

67. Kamato T, Miyata K, Ito H, Yuki H, Yamano M, Honda K (1991) Antiemetic effects of YM060, a potent and selective serotonin (5HT)3-receptor antagonist, in ferrets and dogs. Jpn J Pharmacol $57: 387-395$

68. Kilkenny C (2008) Systematic reviews of animal research. Available online at: http://www.nc3rs.org.uk/downloaddoc.asp?id=695

69. Kim JH, Yoon IS, Lee BH, Choi SH, Lee JH, Lee JH, Jeong SM, Kim SC, Park CK, Lee SM, Nah SY (2005) Effects of Korean red ginseng extract on cisplatin-induced nausea and vomiting. Arch Pharm Res 28:680-684

70. King AG, Sanger GJ (2005) Effect of a selective and potent central nervous system penetrant, neurokinin-3 receptor antagonist (SB-222200), on cisplatin-induced emesis in the ferret. Neurosci Lett 376:5-8

71. Kris MG, Cubeddu LX, Gralla RJ, Cupissol D, Tyson LB, Venkatraman E, Homesley HD (1996) Are more antiemetic trials with a placebo necessary? Report of patient data from randomized trials of placebo antiemetics with cisplatin. Cancer 78:2193-2198

72. Kris MG, Gralla RJ, Clark RA, Tyson LB, O'Connell JP, Wertheim MS, Kelsen DP (1985) Incidence, course, and severity of delayed nausea and vomiting following the administration of high-dose cisplatin. J Clin Oncol 3:1379-1384

73. Kubota Y, Mihara K, Ishii F, Ohno K, Ogata H, Makimura M, Kikuchi N, Kitano T (2004) Effectiveness of anti-emetics for the prophylaxis of cisplatin-induced delayed emesis: a systematic review. Yakugaku Zasshi 124:1-11

74. Lasheras B, Berjon A, Montanes R, Roca J, Romero G, Ramirez MJ, Del Rio J (1996) Pharmacological properties of quinoxaline derivatives as a new class of 5-HT3 receptor antagonists. Arzneimittelforschung 46:401-406

75. Lau AH, Kan KK, Lai HW, Ngan MP, Rudd JA, Wai MK, Yew DT (2005) Action of ondansetron and CP-99, 994 to modify behavior and antagonize cisplatin-induced emesis in the ferret. Eur J Pharmacol 506:241-247

76. Lehmann A, Karrberg L (1996) Effects of N-methyl-D-aspartate receptor antagonists on cisplatin-induced emesis in the ferret. Neuropharmacology 35:475-481

77. Liu YL, Malik NM, Sanger GJ, Andrews PL (2006) Ghrelin alleviates cancer chemotherapy-associated dyspepsia in rodents. Cancer Chemother Pharmacol 58:326-333
78. Macleod MR, O'Collins T, Horky LL, Howells DW, Donnan GA (2005) Systematic review and meta-analysis of the efficacy of melatonin in experimental stroke. J Pineal Res 38:35-41

79. Macleod MR, O'Collins T, Horky LL, Howells DW, Donnan GA (2005) Systematic review and metaanalysis of the efficacy of FK506 in experimental stroke. J Cereb Blood Flow Metab 25:713-721

80. Macleod MR, O'Collins T, Howells DW, Donnan GA (2004) Pooling of animal experimental data reveals influence of study design and publication bias. Stroke 35:1203-1208

81. Marr HE, Davey PT, Blower PR (1992) The effect of dexamethasone, alone or in combination with granisetron, on cisplatininduced emesis in the ferret. Br J Pharmacol 104:371P

82. Marr HE, Davey PT, Boyle EA, Blower PR (1994) Further studies of the antiemetic activity of granisetron against whole body $\mathrm{X}$-irradiation or cisplatin-induced emesis in the ferret. Pharmacology 48:283-292

83. Marr HE, Davey PT, Boyle EA, Blower PR (1994) The antiemetic activity of granisetron against cytostatic-treatment-induced emesis in 10- to 13-week-old ferrets. J Cancer Res Clin Oncol 120:204-207

84. Martin M (1996) The severity and pattern of emesis following different cytotoxic agents. Oncology 53(Suppl 1):26-31

85. Marty M, Kleisbauer JP, Fournel P, Vergnenegre A, Carles P, Loria-Kanza Y, Simonetta C, de Bruijn KM (1995) Is Navoban (tropisetron) as effective as Zofran (ondansetron) in cisplatin-induced emesis? The French Navoban Study Group. Anticancer Drugs 6(Suppl 1):15-21

86. Matsui T, Sugiura T, Nakai H, Iguchi S, Shigeoka S, Takada H, Odagaki Y, Nagao Y, Ushio Y, Ohmoto K et al (1992) Novel 5HT3 antagonists. Isoquinolinones and 3-aryl-2-pyridones. J Med Chem 35:3307-3319

87. Matthews JN, Altman DG (1996) Interaction 3: How to examine heterogeneity. BMJ 313:862

88. Matthews RA (2008) Medical progress depends on animal models-doesn't it? J R Soc Med 101:95-98

89. McCarthy LE, Borison HL (1974) Respiratory mechanics of vomiting in decerebrate cats. Am J Physiol 226:738-743

90. Miller RC, Galvan M, Gittos MW, Van Giersbergen PLM, Moser PC, Fozard JR (1993) Pharmacological properties of dolasetron, a potent and selective antagonist at 5-HT3 receptors. Drug Dev Res 28:87-93

91. Minami M, Endo T, Kikuchi K, Ihira E, Hirafuji M, Hamaue N, Monma Y, Sakurada T, Tan-no K, Kisara K (1998) Antiemetic effects of sendide, a peptide tachykinin NK1 receptor antagonist, in the ferret. Eur J Pharmacol 363:49-55

92. Minami M, Endo T, Monma Y, Shiroshita Y (1991) Pharmacoogy of emesis induced by anti cancer drugs. J Toxicol Sci 16(suppl 2):35-39

93. Minami M, Endo T, Tamakai H, Ogawa T, Hamaue N, Hirafuji M, Monma Y, Yoshioka M, Hagihara K (1997) Antiemetic effects of N-3389, a newly synthesized 5-HT3 and 5-HT4 receptor antagonist, in ferrets. Eur J Pharmacol 321:333-342

94. Miner WD, Sanger GJ (1986) Inhibition of cisplatin-induced vomiting by selective 5-hydroxytryptamine M-receptor antagonism. Br J Pharmacol 88:497-499

95. Miner WD, Sanger GJ, Turner DH (1986) Comparison of the effect of BRL 24924, metoclopramide and domperidone on cisplatin-induced emesis in the ferret. Br J Pharmacol 88:374P

96. Miner WD, Sanger GJ, Turner DH (1987) Evidence that 5hydroxytryptamine 3 receptors mediate cytotoxic drug and radiation-evoked emesis. Br J Cancer 56:159-162

97. Moher D, Cook DJ, Eastwood S, Olkin I, Rennie D, Stroup DF (1999) Improving the quality of reports of meta-analyses of randomised controlled trials: the QUOROM statement. Quality of reporting of meta-analyses. Lancet 354:1896-1900 
98. Monkovic I, Willner D, Adam MA, Brown M, Crenshaw RR, Fuller CE, Juby PF, Luke GM, Matiskella JA, Montzka TA (1988) Substituted benzamides. 1. Potential nondopaminergic antagonists of chemotherapy-induced nausea and emesis. J Med Chem 31:1548-1558

99. Nakayama H, Yamakuni H, Higaki M, Ishikawa H, Imazumi K, Matsuo M, Mutoh S (2005) Antiemetic activity of FK1052, a 5-HT3- and 5-HT4-receptor antagonist, in Suncus murinus and ferrets. J Pharmacol Sci 98:396-403

100. Navari RM, Madajewicz S, Anderson N, Tchekmedyian NS, Whaley W, Garewal H, Beck TM, Chang AY, Greenberg B, Caldwell KC et al (1995) Oral ondansetron for the control of cisplatin-induced delayed emesis: a large, multicenter, doubleblind, randomized comparative trial of ondansetron versus placebo. J Clin Oncol 13:2408-2416

101. Nuffield Council on Bioethics (2005) The ethics of research involving animals. In: Bioethics NCo (ed) London

102. Ohta M, Suzuki T, Furuya T, Kurihara H, Tokunaga T, Miyata K, Yanagisawa I (1996) Novel 5-hydroxytryptamine (5-HT3) receptor antagonists. III. Pharmacological evaluations and molecular modeling studies of optically active 4,5,6,7-tetrahydro-1H-benzimidazole derivatives. Chem Pharm Bull (Tokyo) 44:1707-1716

103. Ozaki A, Sukamoto T (1999) Improvement of cisplatin-induced emesis and delayed gastric emptying by KB-R6933, a novel 5HT3 receptor antagonist. Gen Pharmacol 33:283-288

104. Percie du Sert N, Rudd JA, Moss R, Andrews PLR (2009) The delayed phase of cisplatin-induced emesis is mediated by the area postrema and not the abdominal visceral innervation in the ferret. Neurosci Lett 465:16-20

105. Pound P, Ebrahim S, Sandercock P, Bracken MB, Roberts I (2004) Where is the evidence that animal research benefits humans? BMJ 328:514-517

106. Preziosi P, D'Amato M, Del Carmine R, Martire M, Pozzoli G, Navarra P (1992) The effects of 5-HT3 receptor antagonists on cisplatin-induced emesis in the pigeon. Eur $\mathrm{J}$ Pharmacol 221:343-350

107. Price MT, Olney JE (1990) Excitatory amino acid antagonists as anti-emetics. Soc Neurosci Abstr 16:377

108. Reynolds DJ, Barber NA, Grahame-Smith DG, Leslie RA (1991) Cisplatin-evoked induction of c-fos protein in the brainstem of the ferret: the effect of cervical vagotomy and the anti-emetic 5HT3 receptor antagonist granisetron (BRL 43694). Brain Res 565:231-236

109. Roila F, Hesketh PJ, Herrstedt J (2006) Prevention of chemotherapy- and radiotherapy-induced emesis: results of the 2004 Perugia International Antiemetic Consensus Conference. Ann Oncol 17:20-28

110. Rudd JA, Andrews PLR (2005) Mechanisms of acute and delayed Nausea and vomiting induced by anticancer therapies. In: Hesketh $P($ ed) Management of Nausea and vomiting in cancer and cancer treatment. Jones and Barlett Publishers, Inc., Sudbury, pp 15-66

111. Rudd JA, Bunce KT, Naylor RJ (1992) The effect of 8-OH-DPAT on drug-induced emesis in the ferret. Br J Pharmacol 106:101P

112. Rudd JA, Bunce KT, Naylor RJ (1996) The interaction of dexamethasone with ondansetron on drug-induced emesis in the ferret. Neuropharmacology 35:91-97

113. Rudd JA, Cheng CH, Naylor RJ (1998) Serotonin-independent model of cisplatin-induced emesis in the ferret. Jpn J Pharmacol 78:253-260

114. Rudd JA, Jordan CC, Naylor RJ (1994) Profiles of emetic action of cisplatin in the ferret: a potential model of acute and delayed emesis. Eur J Pharmacol 262:R1-R2

115. Rudd JA, Jordan CC, Naylor RJ (1996) The action of the NK1 tachykinin receptor antagonist, CP 99, 994, in antagonizing the acute and delayed emesis induced by cisplatin in the ferret. Br J Pharmacol 119:931-936
116. Rudd JA, Kan KW, Ngan MP, Okuno T, Sam TS (2001) Antiemetic action of intranasally administered metoclopramide in the ferret. Presented at: 7th Hong Kong Pharmacology Society Scientific meeting in Association with the Zhjiang Pharmacological Society, Hong Kong, China, 16-18 October

117. Rudd JA, Naylor RJ (1994) Effects of 5-HT3 receptor antagonists on models of acute and delayed emesis induced by cisplatin in the ferret. Neuropharmacology 33:1607-1608

118. Rudd JA, Naylor RJ (1994) Modulation of emesis by 5HT1A receptors. Pathophysiology 1:267-268

119. Rudd JA, Naylor RJ (1996) An interaction of ondansetron and dexamethasone antagonizing cisplatin-induced acute and delayed emesis in the ferret. Br J Pharmacol 118:209-214

120. Rudd JA, Naylor RJ (1997) The actions of ondansetron and dexamethasone to antagonise cisplatin-induced emesis in the ferret. Eur J Pharmacol 322:79-82

121. Rudd JA, Ngan MP, Wai MK (1998) 5-HT3 receptors are not involved in conditioned taste aversions induced by 5-hydroxytryptamine, ipecacuanha or cisplatin. Eur J Pharmacol 352:143-149

122. Rudd JA, Ngan MP, Wai MK, King AG, Witherington J, Andrews PLR, Sanger GJ (2006) Anti-emetic activity of ghrelin in ferrets exposed to the cytotoxic anti-cancer agent cisplatin. Neurosci Lett 392:79-83

123. Rudd JA, Sam TS, Ngan MP (2006) A COX and LOX inhibitor regimen fails to mimic the action of dexamethasone on cisplatininduced acute and delayed emesis in the Ferret. IUPHAR-2006, Beijing

124. Ruff P, Paska W, Goedhals L, Pouillart P, Riviere A, Vorobiof D, Bloch B, Jones A, Martin C, Brunet R et al (1994) Ondansetron compared with granisetron in the prophylaxis of cisplatin-induced acute emesis: a multicentre double-blind, randomised, parallel-group study. The Ondansetron and Granisetron Emesis Study Group. Oncology 51:113-118

125. Rupniak NM, Tattersall FD, Williams AR, Rycroft W, Carlson EJ, Cascieri MA, Sadowski S, Ber E, Hale JJ, Mills SG, MacCoss M, Seward E, Huscroft I, Owen S, Swain CJ, Hill RG, Hargreaves RJ (1997) In vitro and in vivo predictors of the anti-emetic activity of tachykinin NK1 receptor antagonists. Eur J Pharmacol 326:201-209

126. Russell WM, Burch RL (1959) The principles of humane experimental technique. Universities Federation For Animal Welfare (UFAW)

127. Rycroft W, Tattersall D, Ber E, Cascieri M, Hale JJ, Hill RG, MacCoss M, Mills SG, Sadowski S, Hargreaves R (1996) The anti-emetic actions of L-742,694, poster

128. Sam TS, Chan SW, Rudd JA, Yeung JH (2001) Action of glucocorticoids to antagonise cisplatin-induced acute and delayed emesis in the ferret. Eur J Pharmacol 417:231-237

129. Sam TS, Kan KK, Ngan MP, Rudd JA, Yeung JH (2003) Action of metyrapone and tetracosactrin to modify cisplatin-induced acute and delayed emesis in the ferret. Eur J Pharmacol 466:163-168

130. Sam TS, Ngan MP, Riendeau D, Robichaud A, Rudd JA (2007) Action of cyclooxygenase inhibitors and a leukotriene biosynthesis inhibitor on cisplatin-induced acute and delayed emesis in the ferret. J Pharmacol Sci 103:189-200

131. Schurig JE, Florczyk AP, Rose WC, Bradner WT (1982) Antiemetic activity of butorphanol against cisplatin-induced emesis in ferrets and dogs. Cancer Treat Rep 66:1831-1835

132. Shiroshita Y, Minami M, Endo T, Monma Y, Asaka M, Itoh H, Ikeda T, Matsumoto H, Satoh T (1993) The protective effect of 4-hydroxy-2-methyl-N-[2-(tetrazol-5-yl)- phenyl]-2H-1, 2-benzothiazine-3-carboxamide-1, 1-dioxide monosodium salt (HX-1920) on cisplatin-induced toxicity in rats. J Toxicol Sci 18:31-41

133. Shiroshita Y, Minami M, Endo T, Takahashi M, Monma Y, Hiromishi I, Yokoyama R, Matsumoto K (1992) Effects of 
HX-1920 on cisplatin-induced toxicity in mice, rat and ferrets. Jpn J Pharmacol 58:419P

134. Singh L, Field MJ, Hughes J, Kuo BS, Suman-Chauhan N, Tuladhar BR, Wright DS, Naylor RJ (1997) The tachykinin NK1 receptor antagonist PD 154075 blocks cisplatin-induced delayed emesis in the ferret. Eur J Pharmacol 321:209-216

135. Spina D (2004) The potential of PDE4 inhibitors in respiratory disease. Curr Drug Targets Inflamm Allergy 3:231-236

136. Stables R, Andrews PLR, Bailey HE, Costall B, Gunning SJ, Hawthorn J, Naylor RJ, Tyers MB (1987) Antiemetic properties of the 5HT3-receptor antagonist, GR38032F. Cancer Treat Rev $14: 333-336$

137. Taniguchi S, Hagihara K, Hamada T, Minami M, Endo T, Tsuchiyama M (2004) The inhibitory action of indisetron hydrochloride, a 5-HT3 receptor antagonist, against the anticancer drug-induced emesis in the dog, ferret and suncus. Jpn Pharmacol Ther 32:799-806

138. Tattersall FD, Dourish CT, Duchnowski M, Swain C, Iversen SD (1990) The anti-emetic action of the novel 5-HT3 receptor antagonist L-683, 877 in the ferret. Eur J Pharmacol 183:1966-1967

139. Tattersall D, Newberry N, Beer MS, Rigby M, Gilbert M, Maguire JJ, Mudukotuwa N, Duchnowski M, MacKnight AT, Swain C, Kneen C, Dourish CT (1992) L-683, 877: Pharmacological Profile of a Novel 5-HT3 Receptor Antagonist. Drug Dev Res 25:17-28

140. Tattersall FD, Rycroft W, Cumberbatch M, Mason G, Tye S, Williamson DJ, Hale JJ, Mills SG, Finke PE, MacCoss M, Sadowski S, Ber E, Cascieri M, Hill RG, MacIntyre DE, Hargreaves RJ (2000) The novel NK1 receptor antagonist MK-0869 (L-754, 030) and its water soluble phosphoryl prodrug, L-758, 298, inhibit acute and delayed cisplatin-induced emesis in ferrets. Neuropharmacology 39:652-663

141. Tattersall FD, Rycroft W, Francis B, Pearce D, Merchant K, MacLeod AM, Ladduwahetty T, Keown L, Swain C, Baker R, Cascieri M, Ber E, Metzger J, MacIntyre DE, Hill RG, Hargreaves RJ (1996) Tachykinin NK1 receptor antagonists act centrally to inhibit emesis induced by the chemotherapeutic agent cisplatin in ferrets. Neuropharmacology 35:1121-1129

142. Tattersall FD, Rycroft W, Hargreaves RJ, Hill RG (1993) The tachykinin NK1 receptor antagonist CP-99, 994 attenuates cisplatin induced emesis in the ferret. Eur J Pharmacol 250:R5-R6

143. The Cochrane Collaboration ${ }^{\circledR}$ (2002) Open Learning Material

144. Tsuchiya M, Fujiwara Y, Kanai Y, Mizutani M, Shimada K, Suga O, Ueda S, Watson JW, Nagahisa A (2002) Anti-emetic activity of the novel nonpeptide tachykinin NK1 receptor antagonist ezlopitant (CJ-11, 974) against acute and delayed cisplatininduced emesis in the ferret. Pharmacology 66:144-152

145. Twissell DJ, Bountra C, Bunce KT, Dale TJ, Gardner CJ, Jordan CC, Ward P (1993) Anti-emetic properties of a non-peptide neurokinin NK1 antagonist, CP-99,994, in ferrets
146. Van Sickle MD, Oland LD, Mackie K, Davison JS, Sharkey KA (2003) Delta9-tetrahydrocannabinol selectively acts on CB1 receptors in specific regions of dorsal vagal complex to inhibit emesis in ferrets. Am J Physiol Gastrointest Liver Physiol 285:G566-G576

147. Watanabe $\mathrm{Y}$, Okamoto M, Ishii T, Takatsuka S, Taniguchi $\mathrm{H}$, Nagasaki M, Saito A (2008) Long-lasting anti-emetic effect of T-2328, a novel NK(1) antagonist. J Pharmacol Sci 107:151-158

148. Watson JW, Gonsalves SF, Fossa AA, McLean S, Seeger T, Obach S, Andrews PLR (1995) The anti-emetic effects of CP-99, 994 in the ferret and the dog: role of the NK1 receptor. Br J Pharmacol 115:84-94

149. Yamakuni H, Nakayama H, Matsui S, Imazumi K, Matsuo M, Mutoh S (2006) Inhibitory effect of zacopride on Cisplatin-induced delayed emesis in ferrets. J Pharmacol Sci 101:99-102

150. Yamakuni H, Sawai-Nakayama H, Imazumi K, Maeda $Y$, Matsuo M, Manda T, Mutoh S (2002) Resiniferatoxin antagonizes cisplatin-induced emesis in dogs and ferrets. Eur J Pharmacol 442:273-278

151. Yoshida N, Omoya H, Ito T (1992) DAT-582, a novel serotonin3 receptor antagonist, is a potent and long-lasting antiemetic agent in the ferret and dog. J Pharmacol Exp Ther 260:1159-1165

152. Yoshida N, Omoya H, Kato S, Ito T (1992) 5-HT3 receptor antagonist effects of DAT-582, (R) enantiomer of AS-5370. Eur J Pharmacol 216:435-440

153. Yoshida N, Omoya H, Kato S, Ito T (1993) Pharmacological effects of the new gastroprokinetic agent mosapride citrate and its metabolites in experimental animals. Arzneimittelforschung 43:1078-1083

154. Yoshida N, Omoya H, Une T, Ito T, kato S (1991) Pharmacological profile of the stereoisomers of AS-5370, a novel 5HT3 receptor antagonist. Jpn J Pharmacol 55(sup 1):385

155. Yoshikawa T, Yoshida N, Hosoki K (1996) Involvement of dopamine D3 receptors in the area postrema in $\mathrm{R}(+)-7-\mathrm{OH}-\mathrm{DPAT}$ induced emesis in the ferret. Eur J Pharmacol 301:143-149

156. Yoshikawa T, Yoshida N, Oka M (2001) Central antiemetic effects of AS-8112, a dopamine D2, D3, and 5-HT(3) receptor antagonist, in ferrets. Eur J Pharmacol 431:361-364

157. Yoshikawa T, Yoshida N, Oka M (2001) The broad-spectrum anti-emetic activity of AS-8112, a novel dopamine D2, D3 and 5HT3 receptors antagonist. Br J Pharmacol 133:253-260

158. Youssefyeh RD, Campbell HF, Airey JE, Klein S, Schnapper M, Powers M, Woodward R, Rodriguez W, Golec S, Studt W et al (1992) Development of high-affinity 5-HT3 receptor antagonists. 2. Two novel tricyclic benzamides. J Med Chem 35:903-911

159. Youssefyeh RD, Campbell HF, Klein S, Airey JE, Darkes P, Powers M, Schnapper M, Neuenschwander K, Fitzpatrick LR, Pendley CE et al (1992) Development of high-affinity 5-HT3 receptor antagonists. 1. Initial structure-activity relationship of novel benzamides. J Med Chem 35:895-903 